\title{
Şah I. Abbas ve Sayın Hanî Türkmenleri Örneğinde Tahakküm ve Direniş
}

\author{
Gülay Karadă̆ Çınar*
}

\begin{abstract}
$\ddot{O ̈}_{\mathbf{z}}$
Harezm bölgesinde ikamet eden Sayın Hanî Türkmenleri Safevî hükümdarı Tahmasb döneminde Harezm'den göç edip Etrek ve Gürgen nehirleri arasına yerleşmişlerdir. Il yani boy sisteminde hanlar, on beyler ve aksakallar tarafindan idare edilmişlerdir. Safevî Devleti ile bağları işledikleri toprağın ya da kullandıkları meranın bedeli olarak ödedikleri vergilerle sınırlı kalmıştır. Kimi zaman da Safevî Şahına sı̆̆ınan Harezmli Özbek şehzadelerin yanlarına destek kuvvet olarak verilmişlerdir. Sayın Hanî diğger adıyla Yaka Türkmenleri kendilerini Safevîler’in bir parçası olarak görmemiş ve yarı bağımsız bir hayat sürdürmüşlerdir. Bu nedenle Esterâbâd'a atanan ve kendisini devletin sahibi gibi gören Kızılbaş valiler ile anlaşamamışlardır. Ağır vergi yükü altında ezilmeleri ve adaletsiz bir yönetimle karşı karşıya kalmaları nedeniyle Esterâbâd valilerine başkaldırmışlardır. Onların memnuniyetsizliklerinden kaynaklı isyanları Şah Tahmasb döneminde başlayıp uzun yıllar devam etmiştir.

Şah I. Abbas'ın saltanatı Sayın Hanî isyanlarının en yoğun yaşandığı yıllardır. Şah, askeri müdahaleler ve yönetim sisteminde gerçekleştirdiği değişimler ile bu isyanların üstesinden gelmeye çalışmıştır. Bizzat eşlik ettiği seferler kaynaklara Horasan seferleri olarak yansıtılmıştır. Feridun Han'ın Esterâbâd valiliğine atanmasıyla yerel yönetim Türkmen isyanlarıyla baş edebilir hale gelmiş ve şahın doğrudan müdahalesi sona ermiştir. Feridun Han ile birlikte Esterâbâd, şaha sadakatini ispatlayan gulâm valilerin idaresine geçmiştir. Böylece vilayet halkının değişim arzuları sadece yöneticilerin kökeninde hayat bulmuştur. Safevî Devleti'nin isyanlarla mücadele yöntemleri değişmediği gibi halkın rahatsızlıkları da ciddi manada sorgulanmamıştır.
\end{abstract}

Anahtar Kelimeler: Safevî Devleti, Sayın Hanî Türkmenleri, Siyâh-pûşân, Esterâbâd, Şah Abbas, Feridun Bey.

* Doç. Dr., Afyon Kocatepe Üniversitesi, Fen Edebiyat Fakültesi, Tarih Bölümü, Afyonkarahisar/ TÜRKIYE, gkaradag@aku.edu.tr ORCID: 0000-0001-7284-7380 DOI: $10.37879 /$ belleten.2021.507 Makale Gönderim Tarihi: 19.08.2020 - Makale Kabul Tarihi: 05.04.2021

Belleten, Ağustos 2021, Cilt: 85/Sayı: 303; 507-544 


\title{
Domination and Disobedience on the Instance of Shah Abbas I and Sayinkhani Turkmens
}

\begin{abstract}
Sayinkhani Turkmens residents of the Khorezm region emigrated from Khorezm to the coast of Atrek and Goorgan rivers in the period of Safavid ruler Shah Tahmasb. Turkmen societies were traditionally divided into tribes named il-el and ruled by chieftains with the title of Khan, Aqsaqal (White Beard), and Onbegi. Their relations with the Safavid State were limited to the paying taxes for cultivated lands or usage pasture. Sometimes they were given as escort to Khorezmian princes taken refuge to Safavid Shahs. Sayinkhani (also known as) Yaqa Turkmens did not see themselves as one group of Safavid and lived a semi-independent life. Therefore Turkmens disagreed with Qizilbash governors appointed to Astarabad and considered themselves as the possessor of state. They rebelled against to Astarabad governors because of heavy tax payments and unfair administration. Caused from their dissatisfaction, rebellions began in the reign of Shah Tahmasb and continued for a long periods.

Sayinkhani rebellions mostly took place during the reign of Shah Abbas II. He tried to overcome these revolts by military interventions and innovations in the local administration system. The campaigns of Shah were called in the Safavid chronicles as Khorasan campaigns. The local government was able to cope with the Turkmen revolts when Faridun Khan was appointed in Astarabad, so Shah's direct intervention ended. Ghulam governors loyal to the Shah was appointed to Astarabad with the beginning period of the governance of Faridun Khan. Thus the desire for change of Astarabad people occurred only at the origin of the rulers. Safavid State did not alter the struggle methods with Turkmen rebellions and not seriously questioned the problems of people.
\end{abstract}

Keywords: Safavid State, Sayinkhani Turkmens, Siyah-pushan, Astarabad, Shah Abbas, Faridun Khan.

\section{Giriş}

Şah I. Abbas'ın saltanat yıllarında Sayın Hanî Türkmenlerinin Esterâbâd vilayetindeki siyasi varlıklarını açıklamayı hedefleyen bu çalışma büyük oranda Safevî kronikleri temelinde şekillenmiştir. Şah Abbas ve sonraki dönemlere ait kronikler bu çalışmaya belli oranda katkı sağlamakla birlikte en tafsilatlı bilgilere Muhammed Tahir Bistamî’nin Feridun Han’a ithafen yazdığı Fütûhât-ı Feriduniyye adlı ve tercüme-i hâl nitelikli eserinden ulaşmak mümkün olmuştur. Eserde Şah Abbas'ın 1015/1606-1607 yılında Esterâbâd'a Emirü'l-Umera olarak tayin ettiği Feridun Han’ın hayat hikâyesine ve fetihlerine yer verilmiştir. Müellif Muhammed 
Tahir Bistamî 1022/1613-1614 yllında ibadet maksadıyla Meşhed’i ziyaret etmiştir. Sonra doğduğu yer olan Bistam'a gitmiş ve Esterâbâd Beylerbeyi Feridun Han'ın huzuruna çıkmıştır. Feridun Han onu Deşt-i Gürgen seferlerini yazmakla görevlendirmiştir. Böylece Deşt-i Gürgen sakinleri ile ilgili emsalsiz bilgilere haiz bu eser ortaya çıkmışır¹.

Şah Abbas dönemini inceleyen modern İran tarihçileri ve batılı araştırmacıların Deşt-i Gürgen ve Mankışlak Türkmenlerinden bahsetmediği görülmektedir². Bu durumun başlıca sebebi Bistamî ve kısmen Münşî dışındaki pek çok Safevî müellifinin Sayın Hanî Türkmenleri hususundaki sessizliğidir.

Şah Abbas, Türkistan-İran sınırını oluşturması münasebetiyle çok önemsediği Esterâbâd valiliğini güvendiği gulâmlarından Feridun Han-1 Çerkes'e vermiştir. Şöyle ki Feridun Han çocuk yaşlarında Safevî Devleti’nin gulâm birliğine dâhil olmuş ve kısa zamanda şahın güvenini kazanmıştır. 1015/1606-1607 yllında Deşt-i Gürgen ve Derun mıntıkasında yaşayan Türkmenlerin, bölge valisi Yusuf Han’ın hastalığa yakalanmasını firsata çevirerek Esterâbâd yönetimini zaafa uğrattıkları bilgisi merkezi hükümete ulaştırılmışır. Şah Abbas, Ramazan 1015/1606-1607 tarihinde Feridun Han’ı bölgeye göndermiş ve isyancı Türkmenlerin cezalandırılmasını emretmiştir. Bu vesileyle Feridun Han Esterâbâd kalesini isyancıların elinden almış ve onları geri püskürtmüş̧ür. Feridun Han'ın bu zaferi Safevî bürokrasisi içerisinde yükselişine zemin hazırlamıştır. Şah Abbas onu bölgenin Emirü'l-Umerası ilan ederek ödüllendirmiştir³.

Esterâbâd Emirüll-Umeralığı Feridun Han’ın sahip olduğu en üst makamdır.

1 Fütûhât-1 Feriduniyye Tahran Üniversitesi Merkez kütüphanesinin El Yazmalar bölümünde 3313 numarada kayıtlı olup İranlı araştırmacılar tarafindan başka bir nüshasına tesadüf edilmediği bildirilmiştir. Nasır Afşar-fer, "Nigâhî be Kitâb-1 Fütûhât-1 Feriduniyye", Ayne-i Mirâs, Devre-i Cedîd III/2, Tahran 1384, s. 249.

2 Felsefî, Zendegân-ı Şah Abbas-ı Evvel adlı çalışmasının üçüncü cildinde Şah Abbas'ın İran'da yaşayan aşiret ve illere (boy) karşı tutumunu değerlendirmiştir. Bu bölümde Kürt aşiretlerin, Lor (Lur) ve Ermeni halkların isimlerini görmek mümkündür. Araştırmacının ifade ettiği üzere İran'da merkeziyetçi bir idare kurmak isteyen Şah Abbas, başına buyruk hareket eden Kızılbaş serdarlarını etkisiz kılma ve adı geçen aşiretlerin isyanlarına son vermek üzere bir politika gütmüştür. Şah isyancı toplumlara yönelik yeni iskân politikası uygulamış ve onları yabancısı oldukları bölgelere dağıtmıştır. Bunun yanı sıra ağır vergilerle onları ekonomik açıdan zayıflatmıştır. Nasrullah Felsefî, Zendegâni-yi Şah Abbâsı Evvel, G III, İntişârât-ı İlmî, Tahran, 1375, s. 1093.

3 Muhammed Tahir Bistamî, Fütûhât-ı Feriduniyye (Şerh-i Cenkhâ-yı Feridun Han-ı Çerkes Emirü'l-Umerâyı Şah Abbas- Evvel), Mukaddime ve Tashih: Seyyid Said Mir Muhammed Sadık-Muhammed Nadir Nasırî-yi Mukaddem, Neşr-i Nokte, Tahran 1380, s. 8-9. 
Onun başlıca görevi Sayın Hanî Türkmenlerini Safevî Devleti’ne tâbi kılmak ve kontrol altında tutmaktır. Deşt-i Gürgen seferleriyle bu amacına ulaştıktan sonra Bistam şehrine yerleşmiştir. Bistam halkı için çok sayıda üzüm bağı kurmuş, halkı bağcılığa ve ziraata teşvik etmiştirł. 1030/1620-1621 yllına kadar vazifesini sürdürmüşs , bu tarihte Saver yaylasında konaklarken hastalanıp vefat etmiştir ${ }^{6}$.

Feridun Han 15 yll süren hükümeti süresince Esterâbâd'da isyan çlkaran, yerleşik halka yönelik baskın ve yağmalar düzenleyen Sayın Hanî Türkmenleri ile şiddetli muharebelere girmiştir. Türkmenlerin her bir isyanına devletin tüm gücüyle müdahale ederek ve çoğu zaman ordusunun başında yer alarak zafer kazanmıştır. Böylece Esterâbâd ve civarında Safevî otoritesini büyük oranda tesis etmiştir. Feridun Han'ın en fazla mücadele etmek durumunda kaldığı isyancı Türkmenler Göklen ve Oklu boylarıdır. Münşî, Feridun Han'ın isyancı Türkmenlerle mücadelelerini birkaç olayla sınırlandırsa da Bistamî’nin biyografik çalışması bu mücadelelerin yirmiye yakın seferden oluştuğunu göstermektedir.

Feridun Han'dan sonra Esterâbâd yönetimi yine Çerkes soylu Behbud Han'a verilmiş̧ir. Ancak Türkmen halk onun yönetiminden memnun kalmayınca kısa zamanda görevinden azledilmiş yerine Şah Abbas'n yakın hizmetindeki gulâmlardan Çerkes Hüsrev Han getirilmiştir ${ }^{7}$. Hüsrev Han 1046/ 1636-37 yılına kadar Esterâbâd Beylerbeyi olarak hizmet etmiş ve ölümünü müteakip bu görev Kazak Han-ı Çerkes'e tevdi edilmiştir ${ }^{8}$. Buradan da anlaşılacağı üzere Esterâbâd valiliği uzun yıllar Çerkes gulâmların idaresine bırakılmıştır. Gürcü ve Çerkes gibi Kafkasya kökenli gulâmların devlet yönetiminde ön plana çıkarılmaları merkeziyetçi politikanın bir neticesidir. Zira uzun müddettir Safevî Şahları için sorun teşkil eden tek Türkmenler Sayın Hanîler değildir. Aynı zamanda Kızılbaş

4 Afşar-fer, agm., s. 252.

5 Bistamî, age., s. 10; Vahid Kazvinî, Feridun Han’ın öldüğü yılı 1031 olarak ifade eder. Onun Esterâbâd valiliğinde geçirdiği süreyi de 18 yıl olarak açıklamaktadır. Mirza Muhammed Tahir Vahid Kazvinî, Târîh-i Cihân Ârâ-yı Abbasî (Abbasnâme), haz. Seyyid Said Mir Muhammed Sadık, Pejuheşgâh-1 Ulum-ı İnsani ve Mutala'at-ı Ferhengî, Tahran 1383, s. 202-203. Veli Kulu Şamlu ise Feridun Han'ın vefat ettiği yıl olarak 1029/1619-20 senesine işaret eder. Veli Kulu bin Davud Kulu Şamlu, Kisasu'l-Hâkânî, C I, haz. Seyid Hasan Sadat Nasırî, Tahran 1371, s. 203.

6 Bistamî, age., s. 11; İskender Bey Münşî, Târîh-i Âlem Ârâ-yı Abbasî, C III, Tashih Muhammed İsmail Rıdvanî, Dünya Kitâb, Tahran 1377, s. 1600.

7 Münşî, age., C III, s. 1600; İskender Bey Münşî-yi Türkmen, Târîh-i Âlem-Ârâ-yi Abbâsî Cilt III 1-23. Kisımlar, Çev: Ali Genceli, Yay. Haz. İsmail Aka, TTK yay., Ankara 2019, s. 65; Behbud Han'ın Esterâbâd valiliğine atanması hususunda bkz. Veli Kulu Şamlu, age., C I, s. 203.

$8 \quad$ Vahid Kazvinî, age., s. 280, 329. 
valililer ve onlara bağlı Türkmen askerlerin de Çaldıran savaşından başlayıp, Şah Abbas'ın öz annesi Mehdi Ulya'nın öldürülmesine kadar giden süreçte devleti zaafa düşüren tutumları ve hanedanı kontrol etme çabaları aşikârdır. Bu durum Şah Abbas'ı orduda ve bürokraside güç dengelerini değiştirme politikasına sürüklemiştir. Şah Abbas, Türkmen Beyler yerine kendisine sadık askerler yetiştirmenin çözümünü paralı askerlik düzeninde görmüş ve yeni birlikleri kullar, tüfekçiler ve topçulardan oluşturmuştur. Bu birliklerde görev alanlar ise genellikle Türk olmayan unsurlardan seçilmiştir ${ }^{9}$. Esterâbâd Beylerbeyi Feridun Han’ın dâhil olduğu Gulâm yani Kullar Birliği, Kafkasya kökenli esir Hıristiyan çocukların İslam dinini kabul etmek ve askeri eğitimlerden geçmek suretiyle katıldıkları süvarilerdir. Şah Abbas tarafindan Kızılbaş Türkmenlerden oluşan Kurçilere

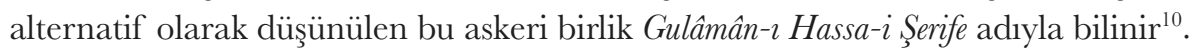
Zamanla gulâmlar Safevî halkının şikâyetçi olduğu Kızılbaş valilerin yerini almıştır. Nitekim şikâyetlerin yoğun yaşandığı Esterâbâd, 1606 yılından itibaren bu politikayla idare edilmiş ve uzun yıllar aynı menşeiden kullarca yönetilmiştir.

Şah Abbas döneminde ülke sınırları vali, beylerbeyi, han ve sultanlar tarafindan idare edilmeye başlanmış ve makam sahiplerinin yetkileri valilerden sultanlara doğru azalmıştır. Yeni süreçte devlet dört büyük hükümet bölgesi ile 13 vilayet olarak idare edilmiştir. Esterâbâd şehri 13 vilayet arasında zikredilmekte ve bölgeye tayin edilen temsilciler yukarıda da ifade edildiği üzere Beylerbeyi unvanıyla anılmaktadırlar ${ }^{11}$. Şah Abbas'ın çağdaşı olan Oruç Bey, Esterâbâd eyaletinin de kendi içerisinde 12 şehirden oluştuğunu ve sadece Esterâbâd merkezde 15.000

9 H.R. Roemer, "The Safavid Period", The Cambridge History of Iran, Volume 6, Ed. Peter Jackson and Laurence Lockhart, Cambridge University press, England 2006; s. 265; Laurence Lockhart, "Safevi Döneminde İran Ordusu", Cihannüma Tarih ve Coğrafya Araştırmalan Dergisi, S. II/2, çev. İlker Külbilge, 2016, s. 181; Richard Tapper, Iran'ın Sinır Boylarnda Göçebeler Şahsevenlerin Toplumsal ve Politik Tarihi, çev. F. Dilek Özdemir, İmge Kitabevi, Ankara 2004, s. 95.

10 R. M. Savory, "Allahverdi Khan (1)" Encyclopaedia Iranica, I/8, pp. 891-892, http://www.iranicaonline.org/articles/allahverdi-khan-d-1, (ET: 14.06.2020); M. Haneda, "Army iii.Safavid Period", Encyclopaedia Iranica, II/5 pp. 503-506, http://www.iranicaonline.org/articles/army-iii (ET: 14.06.2020).

11 Şah Abbas hükümetinin Safevî İran'da belirlediği dört büyük bölge, Arabistan, Luristan, Gürcistan ve Kürdistan'dır. Esterâbâd dışındaki vilayetler ise Kandahar, Şirvan, Herat, Azerbaycan, Çuhursaad (Ermenistan), Karabağ, Kuh-1 Giluyi, Kirman, Merv-i Şah-1 cihân, Ali Şeker (عليشكرHemedan), Meşhed ve Kazvin'dir. Felsefi, age., C I-II, s. 805; Zülfiye Veliyeva, Safevi Devlet Teşkilatı (Tezkiretü'l-Mülük'e Göre), Yayımlanmamış Dr. Tezi, Ankara Üniversitesi Sosyal Bilimler Enstitüsü, Ankara 2007, s. 298-305. 
ailenin yaşadığını belirtmiştir ${ }^{12}$. Burası Safevî kroniklerinde genellikle Esterâbâd ismiyle zikredilmişse de Curcân, Gürgân, Bahriyân ve Deşt-i Kıpçak’ın güney batı uzantısı şeklinde de ifade edilmiştir. Bistamî’nin eserinde ise Deşt-i Gürgân adı kullanılmıştır.

\section{1. Şah Abbas'ın Siyâh-puşân ve Sayın Hanî Türkmenleriyle Sınavı}

Şah Tahmasb sonrası Safevî Devleti’nde Kızılbaş boyların başlattı̆̆ı iç savaşlar devleti zaafa uğratmıştır. Şah II. İsmail'in öldürülmesinden sonraki süreçte Ustaclu, Şamlu, Dulkadir ve Afşar boyları etkinlik kazanmışlardır. Kızılbaşlar Kazvin ve çevresinde etkinliğini sürdürürken çevre bölgelerde yerel seçkinler ön plana çıkmıştır. Bunlardan biri de Esterâbâd'dır.

Şah Tahmasb’ın ölümünün ardından Kızılbaş Beylerin Esterâbâd vilayetinde otorite sağlayamamaları bölgenin yarı-göçebe sakinlerinden Sayın Hanî Türkmen gruplarını cesaretlendirmiştir. Onlardan her bir boy, liderlerine siyah giysiler giydirerek Siyâh-puşân (Siyah Giyimliler) hareketine katılmıştır. Bu Türkmen birliği içerisindeki en küçük boy Eymürler olmasına rağmen Eymür Beyi Aliyâr Han kurduğu iyi ilişkiler sayesinde Türkmenlerin liderliğini ele geçirmiştir ${ }^{13}$.

Muhammed Hüdabende zamanında Safevî hükümetinin gündemini büyük oranda Osmanlı'nın Azerbaycan seferleri meşgul etmiştir. Bunu firsata çevirmek isteyen Aliyâr Han, Esterâbâd şehrine yürümüş ve şehrin dışında yer alan Mübarekâbâd ile Harashâne kalelerini ele geçirmiştir. Aliyâr'ın bu isyanı kısa zamanda vilayetin tamamına yayılmış, Siyâh-puşân hareketi yeniden alevlenmiştir ${ }^{14}$. Muhammed Hüdabende'nin saltanatının son yıllarında Esterâbâd yönetiminde ismi ön plana çıkan Kızılbaş Beyleri Murtaza Kulu Han-1 Pürnek ile Bedir Han-ı Afşar'dır. Her iki vali, Sayın Hanî Türkmen isyanlarına son veremedikleri gibi Münşî’nin ifadesiyle Esterâbâd şehrinin bir fersah ötesine dahi geçememişlerdir. Nihayet Yaka Türkmenlerinin ve Siyâh-puşânların kontrol altına alınamayan davranışları yüzünden vilayeti terk edip Kazvin’e çekilmişlerdir. Dinî lider Hace Şerafeddin-i Saverî idaresindeki bir grup Siyâh-puşân, dönüş yolunda Murtaza

12 Bir Şî̀/Katolik Oruç Bey Bayat/İranl Don fuan, Tercüme ve Notlar Tufan Gündüz, Yeditepe yay., Ankara 2014, s. 28.

13 Münşî, age., C II, s. 845.

14 Münşî bu durumu Siyâh-puşî hareketi yenilendi (رسم سياه يوشى نازه كرديد. şeklinde ifade etmiştir. Münşî,, age., C II, s. 933. 
Şah I. Abbas ve Sayın Hanî Türkmenleri Örneğinde Tahakküm ve Direniş

Kulu ve yanındaki Kızılbaş askerleri durdurup mallarını yağmalamış, at ve silahlarına el koymuşlardır ${ }^{15}$.

Reid'e göre Kızılbaş valilerin bölgeyi terk etmesi üzerine isyanını büyüten gruplar tarım ve basit iş gücüyle hayatta kalmaya çalışan Esterâbâdlı Yaka Türkmenleri, İranlı köylüler ve onlara rehberlik eden Kalender, Kethüda ve Sufi gibi halkın itibar ettiği makam sahipleridir. Ayrıca şehirlerde orta sınıfi oluşturan yerel seçkinler ve din adamlarından müteşekkil tüccar aileler bulundukları yerlerde halkı örgütleyerek isyanı tüm vilayete yaymışlardır ${ }^{16}$. Barthold, Sayın Hanî Türkmenlerinin ekonomilerini tarıma dayandırmakla birlikte Esterâbâd'a düzenlenen yağma seferlerinin payına da ayriyeten dikkat çekmiştir. Şah Tahmasb zamanında Esterâbâd şehrine 15 km mesafede, Gürgen nehri sahilinde inşa edilen Mübarekâbâd kalesi ve burada konuşlandırılan Safevî askerlerinin de malum seferleri geri püskürtmek üzere görev yaptığını hatırlatmıştır ${ }^{17}$.

Barthold'un bu ifadesi akıllara Türkmenlerin ataları Oğuzları getirmektedir. Çünkü onlar Ötüken'de oturup hayvancılık ve tarımla uğraşmışlar ayrıca fetih, yağma türünden seferler tertip ederek siyasi ve iktisadi yönden güçlenmişlerdir. Bu manada Sayın Hanîler’in gerçekleştirdiği Esterâbâd seferlerinin fethin dışında bir amaç taşıdığı ve yağma olarak değerlendirilebileceği ifade edilebilir. Ancak İslamiyet öncesi dönemdeki bağımsız Türk Devletleri ya da boylarının düzenlediği yağma girişimleriyle aynı minvalde değildir. Çünkü Sayın Hanîler tam bağımsız olmadıkları gibi yağma girişimleri de sadece yaşadıkları ekonomik sıkıntıların bir tezahürüdür.

Ekonomik sıkıntıların ve isyanların en önemli gerekçesi Şah Abbas öncesinde Esterâbâd yöneticilerinin Sayın Hanî Türkmenlerinden ağır vergi talep etmeleridir. Esterâbâd'daki Kızılbaş valilerin onlar üzerine oynadığı çeşitli oyunların da etkisi büyüktür. Valiler, Türkmenlerden itibar sahibi kişileri yanlarına çekerek aralarında güvensizlik yaratmışlar, Türkmen Beyleri ulu orta aşağılayarak onur ve gururlarını

15 Münşî-yi Türkmen, Abbâsî II. Cilt-1. Kitap 1-2-3. Kistmlar, s. 259; Münşî, age., C II, s. 934; İhsan İşraki, "Çeşm-i Endâzî be Türkmânân-1 Esterâbâd der Asr-1 Safevî" Ferheng, Şomara 43, Payiz 1381, s. 27-28; Mahbub El-Züveyri, "Siyâh-pûşân, şûreşiyân nâ-şenâhte-i asr-1 Safevî" Kitâb-ı

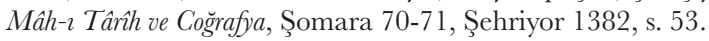

16 James J. Reid, "Rebellion and Social Change in Astarabad, 1537-1744", International Fournal of Middle East Studies, Vol. 13, No.1, 1981, p. 43; James J. Reid, "Esterabad'da İsyan ve Sosyal Değişim (1537-1744)" Türkmenler Üzerine Makaleler, çev. Resul Kürşat Şahsi, Selenge yay., İstanbul 2019, s. 127.

17 V.V. Barthold, Mir Ali Şir ve Türkmen Halkmnn Tarihi, çev. İlhan Aslan, İstanbul 2020, s. 141. 
zedeleyici tavırlar sergilemişlerdir ${ }^{18}$. Netice itibariyle uzun ylllar Harezm Hanlığ ile Safevî Devleti'nin sınır bölgelerinde serbestçe hayvancılık ve tarım yapan karşılığında bağlı oldukları devlete makul vergiler ödeyerek hayatlarını idame ettiren Türkmenler için son gelişmeler katlanılabilir olmaktan çıkmıştır.

Şah Abbas'n saltanattaki ilk yıllarında Kızılbaş birliklerce istihkâm edilen Mübarekâbâd kalesi Sayın Hanîler’in eline geçmiş ve kale yerle bir edilmiştir. İsyana iştirak eden Sayın Hanîler'den her bir boy kendi yerleşim yerlerinde küçük kaleler inşa etmişlerdir ${ }^{19}$. Veli Kulu Şamlu, 997/1588-89 yllında vuku bulan Eymürlü Aliyâr Han'ın isyanını Mâzenderan isyanları arasında saymış ve şahın müdahalesi neticesinde isyanın bastırıldığını ifade etmiştir ${ }^{20}$. Oruç Bey, bizzat tanık olmadığı bu hadiseyi Esterâbâd Beylerbeyi Ali Bey'in isyanı olarak aktarmış ve şahın 30.000 kişilik birlikle bu isyana müdahale ettiğini söylemiştir. Olayların seyrini diğer kaynaklardan farklı nakleden müellif, Ali Bey'in Safevîler'in ilk müdahalesiyle esir düştügünü ve gözlerine mil çekildiğini ifade etmiştir ${ }^{21}$. Oruç

957/1550 yılında Esterâbâd valisi olarak atanan Ustaclu Sultanı Keçel Şahverdi’nin kendisini tebrik etmeye gelen Sayın Hanî Türkmenlerinden Oklu serdarı Abâ'yı yanında zorla alı koyması Abâ için oldukça onur kırııı bir durum yaratmıştır. Şehverdi'nin, Oklu Beyi Şatır ile iyi ilişkiler kurarak bu boyu kontrol altında tutma çabaları da son hadiseye eklendiğinde Oklular için isyan kaçınılmaz olmuştur. Safevî yönetimi uzun yıllar bu isyanı durdurmak için çaba sarf etmiştir. Reid, "Rebellion and Social Change", s. 41; Reid, "Esterabad", s. 123, Gülay Karadağ Çınar, "Esterâbâd'da Safevî Hâkimiyetini Tehdit Eden Unsurlar: Siyâh-Puşân ve Sayın Hanî Türkmenleri”, Avrasya Uluslararast Araştrmalar Dergisi, 8/23, 2020, s. 118.

19 Reid, "Rebellion and Social Change", s. 43; Reid, "Esterabad", s. 127-128.

20 Müellif, Aliyâr Han'ın Deşt-i Kıpçak sakinlerinden olduğunu ve Yaka Türkmenlerine mensubiyetini de ayrıca belirtmektedir. Veli Kulu Şamlu, age., C I, s. 167.

21 Kitapta olayın öncesinde aktarılan bilgi 1000/1591-92 yllında Gilan'da vuku bulan Ahmed Han'ın isyanı ile 1006/1597-98 yılında cereyan eden Mâzenderan isyanıdır. Ayrıca Oruç Bey'in notlarını Türkçe'ye çeviren Tufan Gündüz bu hadiseyi aktarırken 215. dipnotta Şah Abbas'in Estarâbâd'da görevlendirdiği kumandanının Ferhad Han-ı Karamanlu olduğunu yazmaktadır. Bu bilgilerden hareketle ve Oruç Bey'in olayları kronolojiden uzak anlatım metodu dolayısıyla müellifin bahsettiği Esetarâbâd isyanı bizi iki farklı tarihe götürmektedir. Biri ana metinde izah ettiğimiz 997/1588-89 hadisesidir. Oruç Bey’in bahsettiği isyancı lider Ali Bey ile Aliyâr Han'ın aynı kişi olması muhtemeldir. Ancak onun Safevî askeri birliklerince yakalanması ve gözüne mil çekilmesi hadisesi diğer kaynaklarca teyit edilememiştir. 1006/1597-1598 yllındaki hadisede ise kısa bir süre önce vefat eden Aliyâr'ın oğlu Kılıç Han bölge Türkmenlerini temsil etmektedir. O, Şah Abbas'a sadakatle bağlı kalmak suretiyle Esterâbâd'ın yönetimini icra etmektedir. Şu durumda isyan eden Türkmen o değildir. Şahın isyanı bastırdıktan sonra cezalandırdığı Türkmenler arasında Aliyâr Han'ın akrabalarından Nazar Bey-i Eymür de yer almaktadır. Eğer bahsi geçen isyan H.1006 yılında vuku bulduysa Oruç Bey'in ismini zikrettiği isyancı Nazar Bey de olabilir. Zira metnin ilerleyen kısmında yer verildiği üzere Nazar Bey'e Kör Nazar olarak hitap edilmesini sebebi gözlerine çekilen mil olmalıdır. İranh Don fuan, s. 183. 
Bey’in verdiği bu bilgiyle şahın Esterâbâd isyanlarını önemsediği ve kalabalık bir orduyla olaylara müdahale ettiği anlaşılmaktadır.

Askeri girişimlerin sonuçsuz kalması ve Buhara Özbek Hanlığı'nın eş zamanlı Horasan saldırıları Şah Abbas'ı farklı bir politika takip etmek mecburiyetinde bırakmıştır. O, Esterâbâd vilayetini yerel güç odaklarıyla işbirliği yaparak yönetmeyi kararlaştırmıştır. 1588 yılında Sayın Hanî Türkmen Beylerinin iradesiyle seçilen Aliyâr Han'ı Esterâbâd valiliğine atayarak onunla uzlaşmıştır. Böylece hem isyanı durdurmuş hem de Sayın Hanîler ile Buhara Hanı II. Abdullah arasında mezhebe dayalı ve ortak çıkarlar doğrultusunda bir ittifak oluşmassını engellemiştir. Şah Abbas'ın başarılı politikası Sayın Hanî Türkmenlerini II. Abdullah’ın nüfuzu altına girmekten alıkoyduğu gibi Deşt-i Gürgen’in de Safevî yönetiminde kalmasını sağlamıştır².

Reid, Aliyâr Han'ın Safevî hâkimiyetini kabul ederek Siyâh-puşân hareketine ihanet ettiğini söylemiştir. Bu anlaşmayla Eymürlü Aliyâr ve yakın adamları Safevî bürokrasisine dâhil olup Şah Abbas zamanında vücut bulan Şahsevenlik statüsüne ulaşırken Esterâbâd'da düzen değişikliği arayan halk aynı zihniyetteki farklı yöneticilerin idaresine mahkûm olmuşlardır. Değişen tek gerçeklik ise vaktiyle Kızılbaşların değersiz gördüğü yerel seçkinlerin Kızılbaş sisteminin bir parçası haline gelmeleridir ${ }^{23}$.

Abisaab’a göre Sayın Hanî isyanlarına son vermek üzere müzakereler kapısını her daim açı tutan Şah Abbas askeri gücü, uzlaşmacı tavrıyla dengelemeye çalışmıştır. Ayrıca hassas ittifaklar yaratarak Safevî Devleti’ne güç devşirmiştir. İlerleyen yıllarda Feridun Han'ın kimi zaman uzlaşmacı tavır takınması da Şah Abbas'ın yönetim anlayışının bir parçasıdır ${ }^{24}$. Şah Abbas'ın yerel güçlerle ittifakı coğrafî şartlardan da kaynaklanmaktadır. Deşt-i Gürgen'de yolların dar, geçitlerin

22 Münşî, age., C II, s. 845- 846, 934; Münşî-yi Türkmen, age., II. Cilt-1. Kitap 1-2-3. Kısımlar, s. 194, 259-260; Züveyri, agm., s. 52; Reid, Aliyâr Han'ın Safevî Devletine itaatinden önce Ebiverd, Nesa, Derun ve Bağbad'ı ele geçiren Buhara Hanı II. Abdullah'a tabi olduğunu söyler. Reid, "Rebellion and Social Change", s. 44; Reid, "Esterabad", s. 128-129; Abdullah Han'in Horasan seferleri ve I.-II. Herat kuşatması uzun bir zamana yayılmıştır. Seferler 1567 yılında başlamıştır. 1593 yılına gelindiğinde ise Özbek seferleri Gürgen/Curcân vilayetinde yaşayan Giraylı ulusuna kadar ulaşmıştır. Ayrıntılı bilgi için bkz. Gülay Karadağ Çınar, Safevî-Özbek Siyasî İlişkileri ve Osmanlı'nın Tesiri (1524-1630), Yayımlanmamış Dr. Tezi, AKU Sosyal Bilimler Enstitüsü, Afyonkarahisar 2011, s. 117-118, 191-213.

23 Reid, "Rebellion and Social Change", s. 44; Reid, "Esterabad", s. 129.

24 Rula Jurdi Abisaab, "Peasant Uprisings in Astarabad: the Siyâh Pûshân (wearers of black), the Sayyids, and the Safavid State", Iranian Studies, 49/3, s. 483. 
tehlikeli ve dağlık bölgenin ormanlarla kaplı olması Safevî birliklerinin bölgeye müdahale etmelerini zorlaş̧ırmıştır. Dolayısıyla Gürgen ovası Yaka Türkmenlerinin yaylak ve kışlak sahası olarak kalmıştır. Siyâh-puşân hareketine iştirak eden Türkmenler şehirlere ve ormanlık alanlara da yerleşmişlerdir ${ }^{25}$.

Şah Abbas, batıda Osmanlı doğuda Özbeklerle yaptı̆̆ı savaşlar ve içerde Kızılbaş Beylerin muhalefeti nedeniyle Esterâbâd politikasını uzun bir süre değiştirememiştir. Esterâbâd valisi Aliyâr Han 1005/1596-1597 yllında vefat edince henüz yirmi yaşını aşmamış olan oğlu Muhammed Yar Han, şahın huzuruna gelip itaatini arz etmiş ve bu sayede babasının makamında görevlendirilmiştir ${ }^{26}$. Ancak Sayın Hanî Türkmenlerinden Oklu boyu, Muhammed Yar'ın idaresine karşı çıkmıştır. Muhammed Yar ile Oklu ili arasındaki anlaşmazlıklar 1006/159798 yılında Oklu isyanının patlaması ve yeni Esterâbâd valisinin öldürülmesiyle neticelenmiştir. Akabinde Aliyâr'ın küçük oğlu Kılıç Han aynı yolla vilayetin yönetimini devralmış ancak ülkedeki isyan ateşini bir türlü söndürememiştir. $\mathrm{Bu}$ son gelişmeler üzerine Şah Abbas Horasan seferini başlatmıştır. Asıl hedefi Gürgen vilayetinde sükûneti sağlamaktır. Kendisi Bistam'da ordugâh kurarken emirlerinden Ferhad Han'ı Mâzenderan valiliğine atamış ve Esterâbâd'ı düzene koymakla görevlendirmiştir. Merkezi ordunun Esterâbâd'da görünmesi üzerine Sayın Hanî Türkmenleri akıbetlerinden endişe ederek devlete itaat etmişler hatta şahın devam eden Horasan seferi için orduda görev almayı istemişlerdir ${ }^{27}$.

Şah Abbas, Horasan seferini tamamlayıp Irak tarafina yöneldiğinde ona eşlik edenler arasında Kılıç Han, ailesi ve kendisine tabi olanlar da bulunmaktadır. Şahın ardından Sayın Hanî Türkmenlerinin Esterâbâd yönetimine bağllığı devam etmiştir. Oklu Türkmenlerine ilaveten Eymür ve Salur boyları da tabiiyeti ka-

25 Münşî-yi Türkmen, age., II. Cilt-1. Kitap 1-2-3. Kısımlar, s. 259; Münşî, age., C II, s. 934.

26 Muhammed Yar'in Şah Abbas ile iletişimini Esterâbâd seyyidlerinden Mir Ziyaeddin’in oğlu Mirza Bey-i Fendereskî sağlamıştır. Fendereskî, Muhammed Yar Han’ın devletin bekasını isteyenlerden biri olduğuna ve Safevî hanedanlığına sadakatine şahitlik ederek Muhammed Yar'ın başkent Isfahan'da şahın huzuruna çımasına ve eteğini öpmesine vesile olmuştur. Münşî, age., $\mathrm{C}$ II, s. 845, 947; Ali Genceli'nin tercümesinde Muhammed Yar'ın yaşı için gençliğinin ilk devresinde olduğu ifade edilmiştir. Münşî-yi Türkmen, age., II. Cilt-1. Kitap 1-2-3. Kısımlar, s. 193, 269.

27 Münşî, age., C II, s. 935, 947; Münşî-yi Türkmen, age., II. Cilt-1. Kitap 1-2-3. Kısımlar, s. 213, 260, 269. Reid, "Rebellion and Social Change", s. 44; Reid, "Esterabad", s. 129; Veli Kulu Şamlu Ferhad Han'nn Mâzenderan vilayetinde görevlendirildiği ve onun gayretiyle vilayette kontrolün sağlandığı yılı 1002/1593-94 olarak açıklar. 1006/1597-98 yllını ise Ferhad Han'ın ölüm yllı olduğunu belirtir. Veli Kulu Şamlu, age., C I, s. 182-183. 
bul etmişler hatta boy beylerinden Kör Nazar adıyla tanınan Nazar Bey-i Eymür, Hüseyin Han'a tabi olmuş ve vilayet memurluğuna atanmıştır ${ }^{28}$.

Oklu boyu başta olmak üzere isyancı Türkmenlerin sessizliği kısa sürmüş ve Karihan liderliğinde ayaklanmışlardır. Evâil-i 1007/Ağustos-Ekim 1598 tarihinde Mâzenderan vilayeti Hüseyin Han-ı Ziyadoğlu Kaçar'a verilmiştir. Tabi bu görevle birlikte Esterâbâd'daki Yaka Türkmenleri ve Siyâh-puşân’ı kontrol altında tutmaktan da bilfiil Hüseyin Han sorumlu tutulmuştur. Şah Abbas ayrıca Oklu Türkmenlerinin merkezi hükümetle ilişkilerini düzenlemek için onların şüphe duymayacağı, Oklu boyu ile akraba Çağataylılara mensup aynı zamanda Safevî sarayının Emir-i Ahur-başısı olan Muhammed Kulu Bey’i Karihan'ın yanına göndermiştir. Muhammed Kulu Bey Karihan’dan Safevî hükümetine tabi olması ve isyanına son vermesini istemiştir. Bu tabiiyeti meşru kılacak amil ise Harezm Han'ı Hacı Muhammed'in oğullarıyla birlikte Safevî Devleti’ne sığınması müellifin ifadesiyle; bir müddet devletin talihli gölgesinde bulunmasıdır. Nitekim Türkmenler geçmişte bu hanlığın reayası idi. Öyleyse Hacım Han’ın Safevî mensubu olduğu yeni dönemde Yaka Türkmenleri de Şah Abbas'a tabiiyetlerini bildirmeliydiler. Muhammed Kulu Bey, şahın ordusu Türkmen yurduna ulaştığı vakit Türkmen ileri gelenlerinin kendisiyle birlikte Şah Abbas'ı karşılamalarını ve yüce eşiğini öperek şereflenmelerini teklif etmiştir ${ }^{29}$. Ayrıca Türkmenlere edep çizgisinden

28 Münşî, age., C II, s. 947; Münşî-yi Türkmen, age., II. Cilt-1. Kitap 1-2-3. Kısımlar, s. 269. Yezdî, Aliyâr Eymür'ün oğlu Muhammed Yar'ın şahın huzuruna çıkıp etek öpmesi, aynı şekilde Eymür ileri gelenlerinden Nazar Sultan'ın itaatini arz etmesi hadisesini Şah Abbas'ın 1008/1599'daki Horasan seferinden sonra gerçekleşmiş gibi anlatır. Akabinde Mâzenderan'daki Elvend Div isyanına yer vermesi müellifin kronolojide yanlışlık yaptı̆̆ı şeklinde değerlendirilebilir. Molla Celaleddin Muhammed Müneccim Yezdî, Târîh-i Abbasîy â Rûznâme-i Molla Celal, Be Kûşeş: Seyfullah Vahidniya, İntişârât-1 Vâhid, 1366, s. 188-190.

29 Münşî, age., C II, s. 906-907, 935, Münşî-yi Türkmen, age., II. Cilt-1. Kitap 1-2-3. Kısımlar, s. 239, 260-261; Şah Abbas'ın Hüseyin Han'ın selefi Ferhad Han'ın katline ferman vermesi ve bu emrin icra edilmesi ile ilgili bkz. Celaleddin Yezdî, age., s. 184; Reid, Ferhad Han ile onun öldürülmesinin ardından makamına tayin edilen Hüseyin Han'ı Esterâbâd valisi olarak aktarmaktadır. Ancak esasında bu iki emir Mâzenderan valisi olarak atanmışlardır. Anlaşıldığı kadarıyla Murtaza Kulu Han-ı Pürnek’in Mübarekâbâd kalesinden kaçar gibi ayrılmasından sonra Safevî hükümeti bölgeye bir süre vali tayin etmemiş ve Esterâbâd'daki hareketliliği Mâzenderan valiliği vasıtasıly denetlemiştir. Münşî, Mâzenderan valiliğine Ferhad Han'ın atanmasından itibaren valinin yetki alanına, bölgeye yakın olması münasebetiyle Esterâbâd'ın da eklendiğini söyler. Şahın fermanı Esterâbâd halkına, ayanına ve Siyâh-puşân yöneticilerine ulaştırılarak onlardan Ferhad Han-ı Karamanlu'ya meyletmeleri istenir. Müellif, her iki Mâzenderan valisinin Esterâbâd'daki ayaklanmayı durdurmaları yönündeki vazifelerini de ayrıca kaydetmiştir. Reid ayrıca Hüseyin Han'ın ismini de sehven Hasan Han olarak kaydetmiştir. Reid, "Rebellion and Social Change", s. 44-45; Reid, "Esterabad", s. 130. 
ayrılmadıkları müddetçe şahın ordusundan korkmamalarını, eski yurtlarının ve mevkilerinin koruma altına alınacağını ve şahın kendilerine şefkat ve lütufta bulunacağını bildirmiştir ${ }^{30}$. Esasında Muhammed Kulu Bey her cümlesiyle şahı överken Türkmenlerin içinde bulunduğu âcizliği de fark etmelerini istemiştir.

Şah Abbas'ın, Oklu Türkmenleriyle görüşmek ve müzakere kapısını aralamak üzere Çağatay gibi seçkin ve Yaka Türkmenleriyle akraba bir boy liderini seçmesindeki esas gaye Okluların işittiklerine itibar etmeleri ve Safevî hükümetine karş1 olumsuz düşünceleri terk etmeleridir. Nitekim Şah Abbas Türkmenlere bu mesajlarını gönderirken kendisi de ordusunu hazırlamış ve Siyâh-pûş serdarlarının kılavuzluğunda Kebûd-câme yolundan harekete geçmiştir. Bu sırada Esterâbâd'da bulunan Safevî heyeti iyi bir şekilde ağırlanmakta Karihan'ın da dâhil olduğu Oklu ileri gelenleri ile Safevî heyeti arasında ateşkes görüşmeleri gerçekleştirilmektedir. Görüşmeler esnasında Safevî Devleti'ne itaate razı olmayan bir grup Oklu mensubu Etrek nehri yakınlarına kaçmış, başka bir grup da toplantının gerçekleştiği çadıra ani bir baskın düzenlemiştir. Muhammed Kulu Bey ve adamları obanın dışına çıkarak onlara karşı koymaya çalışmışlardır. Ancak Oklularla mücadelede başarısız olmaları ve Muhammed Kulu'nun ağır bir yara almasıyla derhal şahtan destek talep etmişlerdir. Zaten isyancı Türkmenler üzerine sefer için yollara düşen şah, savaş düzeni almıştır. Ordunun bir bölümünü Oklu obası üzerine sevk etmiş, kendisi de muhafiz birliğiyle Etrek nehri çevresine göç eden Oklular’a karşı yürüyüşe geçmiştir.

Safevî birliğinin Etrek nehrine varmasılla Karihan ve emrindeki Oklular Deşt-i Kıpçak tarafina kaçmışlardır. Netice itibariyle Etrek ovasında kalan Türkmen erkekler öldürülmüş, kadın ve çocuklar esir alınmıştır. Safevî askerleri Türkmenlerin tüm mallarına, eşyalarına, koyunlarına ve binek hayvanlarına el koymuşlardır. Ancak Karihan’ın izine rastlanmadığı için çölde belirsizce ilerlemek yerine geri dönmeye karar vermişlerdir. Bu birlik Gürgen nehri kenarında Kümbedî ${ }^{31}$ mevkiinde orduya dâhil olmuş oradan da Mübarekâbâd kalesine ilerlemiştir. Kaleyi

30 Münşî, age., C II, s. 936, Münşî-yi Türkmen, age., II. Cilt-1. Kitap 1-2-3. Kısımlar, s. 261; Celaleddin Yezdî, age., s. 187; Lucien Louis Bellan, Zendegîi Şah Abbas, Tercüme Dr. Veliullah-1 Şâdân, İntişââat-1 Esatir, 1375, s. 126.

31 Kümbet, Şemsü'l-Me'âlî Kâbus bin Veşmgir'in defnedildiği yerdir. Kâbûs b. Veşmgîr 367/978 yllında Taberistan ve Cürcân'ın Ziyârî emiri olarak tahta çımıştır. Sâmânîler'e karşı Büveyhîlerin desteğini almış ve bu sebeple tahta çıkar çıkmaz Büveyhî Sultanı adına hutbe okutarak tabiiyetini bildirmiştir. Bahsi geçen mezarı 397/1006-1007 yllında bizzat kendisi inşa ettirmiştir. Ölümünün ardından cenazesi oraya defnedilmiştir. Ahmet Güner, "Kâbûs b. Veşmgîr" DİA, C 24, Türkiye Diyanet Vakfi yay., İstanbul 2001, s. 43-44. 
Şah I. Abbas ve Sayın Hanî Türkmenleri Örneğinde Tahakküm ve Direniş

ele geçiren Şah Abbas, idaresini gulâmlarından Topçubaşı Berhordâr Bey-i Enis'e vermiştir. Bu sırada Sayın Hanîler'e mensup bir grup Aksakal, Şah Abbas'ın gazabından korkarak bağımsızlık arzularından vazgeçip şaha itaatlerini bildirmiş$\operatorname{lerdir}^{32}$.

Şah ilk iş olarak Mübarekâbâd kalesinin tamirini buyurmuştur. Akabinde kale çevresini emir ve askerleri arasında taksim etmiştir. 12 gün zarfinda tamir işleri son bulunca Siyâh-pûşân temsilcilerini huzuruna çağırıp onlara şöyle hitap etmiştir:

"Kaç yıldır bu memleket işbilen vali yönetiminden mahrum, düzen ve muhafazadan uzak idi ve siz her biriniz kendinizi koruma altına almak üzere tabilik yolundan ayrıldınız ve (bizimle) savaşa kalkıştınız. Birbirilerinizin korkusundan ve Siyâh-pûşân Türkmen taifesinin zarar ziyanından toplanıp sizden Kızılbaş emirlere karşı bazı ölçüsüzlükler (ölçüsüz davranışlar) vuku buldu. Şimdi geçmişte karışıklık zamanlarında gerçekleştirdiğiniz ve merkezce göz yumulan işlerden pişman olup özür ve tabiiyet noktasına geldiniz. Biz de sizin geçmişteki işlerinizi olmamış gibi düşünüyoruz." "33

Münşî, şahın kaç yıldır ifadesiyle yuvarladığı zaman diliminin 25 yıldan daha fazla olduğunu aktarmaktadır. Şah Abbas'ın o anda yaşları 25 civarında olan gençlerin hiçbir şekilde Kızılbaş Emirine itaat etmediği hatta bunların herhangi bir vali görmedikleri için kendilerini bölgenin hâkimi olarak düşündüklerini, gurur ve kibir ateşinin onların zihinlerinde önemli bir yer tuttuğunu ifade etmiştir. Şahın bu müdahalesiyle de Siyâh-puşân Türkmenlerinin gaflet uykusundan uyandığını belirtmiştir ${ }^{34}$. Araştırmacı Züveyri, Şah Abbas'ın bu sözlerini naklettikten sonra

32 Münşî, age., C II, s. 937-938; Münşî-yi Türkmen, age., C II-1. Kitap 1-2-3. Kısımlar, s. 261- 262; Yezdî Etrek’te Oklulara karşı gerçekleştirilen baskını biraz daha detaylı aktarır. Buna göre Şah Abbas 3 Rebiü'l-sani 1008/ 23 Ekim 1599 tarihinde Kümbed-i Kabus'da mola vermiş, bu esnada Muhammed Kulu Bey’in Oklu boyu içerisinde kötü muamele gördüğü haberini almıştır. Derhal harekete geçen merkezi ordu şahın idaresinde Türkmenlere karşı saldırılara başlamıştır. Netice itibariyle Safevî askerleri Etrek nehri sahilindeki yaklaşık 700 Oklu mensubunu öldürmüş obadaki Türkmen kadınları, kız ve erkek çocukları, at, deve, inek, koyun ve ne kadar değerli eşya varsa hepsine el koymuşlardır. Celaleddin Yezdî, age., s. 187-188; Reid, "Rebellion and Social Change", s. 45. Reid, "Esterabad", s. 130, İşraki, agm., s. 28.

33 Münşî, age., C II, s. 938; Vahid Kazvinî, age., s. 145; Yezdî kale tamirinin Evâsıt-1 Rebiü’l-Sani 1008 yani 1599 yılı Kasım'ın ilk haftası gibi başladığını ve 14 gün kadar devam ettiğini söyler. Ayrıca kaledeki görev taksimatını da ayrıntılı olarak aktarır. Buna göre kalenin doğu surları Kurçiyan birliğine, kuzey surları emirlere ve batı surları gulâmların kontrolüne teslim edilmiştir. Kalenin güney cephesi ise şahın emrindeki vezirlere ve işinin başında olan halka emanet edilmiştir. Celaleddin Yezdî, age., s. 188.

34 Münşî, age., G II, s. 938; Münşî-yi Türkmen, age., C II-1. Kitap 1-2-3. Kısımlar, s. 262. 
Siyâh-pûşân'ı kendi amaçlarına ulaşmak için huzursuzluk ve düzensizliklerden istifade eden ücretli fedailer topluluğu olarak tanımlamıştır. Zengin olmak hayaliyle isyana kalkıştıklarını ve Hace Saverî gibi bir köle tacirinin şeytani emellerine hizmet ettiklerini söylemiştir ${ }^{35}$. Tabi onun burada ifade ettiği güruh sadece Saverî’nin emrinde hareket edenlerdir.

Kanaatimizce Şah Abbas'ın bu konuşması Esterâbâd vilayetinde uzun süredir devam eden kargaşanın sebeplerine dair tespitler ve çözüm yolları sunmaktadır. Şah Abbas'a göre bölgedeki isyanların sebepleri; bölge valilerinin yetersizliği, yereldeki rekabet ve çatışmalar ile Siyâh-puşân’ın aşırıya kaçan eylemlerinin halkta yarattığı memnuniyetsizliktir. Suçu öncelikle kendi valilerinde gören Şah Abbas isyancı halkı affettiğini bildirmiştir. Horasan seferi neticesinde Cürcân (Gürgen), Taberistan ve Murgab sahiline kadarki Horasan vilayetlerinin hâkimiyet altına alındığını, Harezm ve Ürgenç’teki Özbek hanlarının Safevî himayesini kabul ettiklerini ve isyana devam eden Sayın Hanî Türkmenlerinin ise cezalandırıldı̆̆ını söylemiştir. Şah, halkı teskin etmek adına bundan sonraki süreçte Türkmenlere karşı zorbalık uygulayan, haklarına ve mallarına tecavüz eden yöneticilere geçit vermeyeceğini bildirmiştir. Karşılığında ise Türkmenlerin ellerindeki silahları bölgedeki Safevî idaresine teslim etmelerini, karşı mücadele yürüttükleri kaleleri yıkmalarını, eskisi gibi ziraat ve bölgenin imarı ile meşgul olmalarını istemiş, Safevî valisinin bölgeyi Mübarekâbâd'dan yöneterek her türlü tehlikeyi bertaraf edeceğini beyan etmiştir. Böylece taraflar arasında karşılıklı güven ve itimat ortamının sağlanacağını öngörmüştür. Sayın Hanîler de Münşî’nin ifadesiyle başka çareleri olmadığı için şahın bu teklifini kabul etmişlerdir ${ }^{36}$.

Şah Abbas'ın bölgede otoriteyi sağlamak üzere ikinci girişimi Hace Şerafeddin Saverî ve emrindeki Siyâh-pûşân’ın cezalandırılmasıdır. Şah Abbas, Saverînnin Esterâbâd halkına türlü zulümler yaptığını işitmiştir. Örneğin isyancılar gece baskınlarıyla varlıklı olanların malına el koymuş, kendilerine de işkence etmişlerdir. Kadınların namusuna el uzatmış hatta bir defasında hamama girip çıplak kadın-

Münşî’nin aktardığına göre Şah Abbas'ın Türkmenlere verdiği sözlere ve aksakalların bu sözler
çerçevesinde tekrardan Safevî himavesine girmis olmasına rağmen tavin edilen Kızılbas emirler nizamı yeniden sağlamak adına şiddet içerikli uygulamalara devam etmişlerdir. Türkmen boy mensuplarının evinde kılıç ya da mızrağa rastlanması halinde bedelini canıyla ödedikleri olaylar vuku bulmuştur. Bu durum da gösteriyor ki Safevîli yöneticiler yaşanılanlardan hiçbir ders çıarmadıkları gibi şahın emirlerine de riayet etmemişlerdir. Böylece Esterâbâd vilayetindeki Türkmenlerin isyan ateşi bir türlü son bulmamıştır. Münşî, age., C II, s. 938-939; Münşî-yi Türkmen, age., II. Cilt 1. Kitap 1-2-3. Kisimlar, s. 262-265.

Belleten, Ağustos 2021, Cilt: 85/Sayı: 303; 507-544 
Şah I. Abbas ve Sayın Hanî Türkmenleri Örneğinde Tahakküm ve Direniş

ları yakalayarak hepsini Saver şehrinde satmışlardır. Şah bu duruma son vermek için Murtaza Kulu Han aracılığıyla Saverî’yi Esterâbâd'da huzuruna çağırmıştır. Saverî daveti kabul edip şahı ziyaret etmiş ve ondan af dilemiştir. Ancak şah onun öldürülmesini emretmiştir. Saverî’nin cesedi parçalara ayrılarak Esterâbâd'ın sokaklarına ve bahsi geçen hamama atılmış ve böylece isyana meyledeceklerin ibret alması istenmiştir. Vilayetin genelinde huzurun ve emniyetin sağlandığından emin olan Şah Abbas, Esterâbâd'dan ayrılıp Irak tarafina yönelirken Hüseyin Han'ı doğrudan Esterâbâd hâkimi olarak atamıştır. Hüseyin Han vilayette tüm tedbirleri sıkı tutmuş isyanın bir daha ortam bulmaması için tehdit gördüğü herkesi ortadan kaldırmıştır ${ }^{37}$.

Abisaab, Safevî hükümdarlarının Şah Tahmasb’ın saltanatından itibaren liderlik kadrosunda din adamlarının etkin olduğu Siyâh-puşân hareketini kesinlikle hafife almadığını ima eder. Ona göre Safevî hanedanlığı bin yıllık sufi geleneğinin sonucunda ortaya çıkmış hükümdar ailesidir. Bu nedenle herhangi bir sufi hareketinin mevcut siyasi düzen için ne tür tehditler yaratabileceğinin farkındadır ${ }^{38}$. Abisaab, geniş bir pencereden bakarak sufiliği ve sufi hareketlerin devlet otoritesi karşısındaki gücünü çok eskilere dayandırsa da Kafkasya ve Orta Doğu toplumları nazarında sufilik özellikle 12. yüzyıldan itibaren değer kazanmıştır. Erdebil tarikatı ise 13. yüzyılda ortaya çıkmış, giderek artan taraftar sayısıyla siyasi güç devşirmiş ve 16. yüzyılın başında devlet statüsü kazanmıştır. Şah Abbas'ın Saverî liderliğindeki isyana dönük sert politikası da bu minvalde değerlendirilebilir. Muhtemelen Şah, alınan sıkı tedbirlerle Siyâh-pûşân hareketinin gücünü kırmak, Safevî Devleti için daha yıkıcı sonuçlar yaratmasını engellemek istemiş ve bunu da başarmıştır.

Bu tarihten sonra Esterâbâd'da gerçekleşen ilk büyük isyan hareketi Reid'e göre Şah Abbas'ın ölüm yılı olan 1629'da Rahman Kulu Sultan tarafindan yönetilmiştir ${ }^{39}$. İşraki'nin Şah Abbas dönemi için en son aktardığı isyan, Saverî idaresindeki Siyâh-puşân ayaklanmasıdır. Araştırmacı, Şah Abbas'ın isyancılara karşı sert tutum geliştirmesinin ve onları en ağır şekilde cezalandırmasının neticesinde İan'da iç isyanların son bulduğunu ve güvenlik probleminin kalmadığını söylemektedir. Şahın bu tutumunun da devletin istikrarı için gerekli olduğunu

37 Münşî, age., C II, s. 939-941; Bellan, Saverî’nin mesleğini köle tüccarı olarak açılamaktadır. Bellan, age., s. 126.

38 Abisaab, agm., s. 476.

39 Reid, "Rebellion and Social Change", s. 46; Reid, "Esterabad", s. 132. 
vurgulamaktadır ${ }^{40}$. Züveyri de benzer bir üslupla şahın sıkı kontrolü sonucunda Siyâh-puşân'ın zihninden isyanın silindiğini ve İran'ın diğer vilayetlerinde olduğu gibi Esterâbâd'da da güvenliğin sağlandığını belirtmektedir ${ }^{41}$. Ancak bu tespitler gerçeği yansıtmamaktadır. Muhtemelen modern tarihçileri yanılgıya düşürerek Abbas'ın saltanatının ilk yıllarında Esterâbâd'da isyan meselesinin çözüldüğü zannına sebep dönemin maruf Safevî kroniklerinde Esterâbâd isyanlarıly ilgili bilginin sınırlı olmasıdır. Ancak Feridun Han-ı Çerkes'in Deşt-i Gürgen ve Deşt-i Kupçak fetihlerini konu alan Fütûhât-ı Feriduniyye adlı kronik durumun böyle olmadığını göstermektedir ${ }^{42}$.

\section{2. Şah Abbas'ın Esterâbâd Vilayetinde Gulâm Sistemine Geçişi}

1599 yılı sonrasında Sayın Hanî Türkmenleri yeniden yağma ve baskınlara başlamıştır. 1011/1602-1603 ylında Şah Abbas'ın bizzat müdahalesiyle Derun'da yaşayan Özbek ve Sayın Hanî Türkmenleri kontrol altına alınmış, şehrin Özbek darugası ve isyancıların bir kısmı öldürülmüş, çok sayıda kişi bölgeden göç ettirilmiştir. Şah Abbas şehrin yönetimini Ali Han’a teslim etmiş ve kendisi 4 Cemaziye'l-evvel 1011/20 Ekim 1602'de Tevekkül Han-1 Giraylı'ya misafir olmuştur ${ }^{43}$. Onun bu ziyareti Giraylı boyunu Sayın Hanî Türkmenleri ve Özbeklerle ittifaktan uzak tutma girişimi olarak okunmalıdır. Aynı yıl içerisinde Etrek nehri kenarında yaşayan Göklenler isyan etmişler ve bu isyan Derun hâkimi Ali Han tarafindan bastırılmıştır. İsyancılardan 70 kişiyi öldürmüş, çok sayıda esir ve ganimet ele geçirmiştir ${ }^{44}$.

Safevîler gerçekleştirdikleri Deşt-i Gürgen seferlerinde çoğunlukla Oklu ve Göklen boylarından birçok esir ele geçirmişlerdir. Esterâbâd valileri Şah Abbas'm emriyle Türkmen esirlere köle muamelesinde bulunmamıslardır. Esir kadın ve çocuklar

40 İşraki, agm., s. 29.

41 Züveyri, agm., s. 53.

42 Abbas'ın resmi tarihçisi Münşî tarihi biraz daha öteleyerek Feridun Han’ın elde ettiği zaferler neticesinde ölümünden sonra da bölgede sükûnetin bozulmadığını ve Türkmenlerin bir nizam içerisinde yaşadıklarını söylemiştir. Müellifin bu tavrı şahın siyasi başarısını övme çabası olarak değerlendirilmektedir. Zira Türkmenlerin Şah Safi dönemi itibariyle Safeviler akabinde Afşar ve Kaçar yönetimlerinde de bağımsızlık arayışlarını sürdürdükleri görülmektedir. Münşî, age., C III, s. 1600; Münşî-yi Türkmen, age., III. Cilt 1-2-3. Kısımlar, s. 64-65; Şah Abbas sonrası Esterâbâd olayları için bkz. Reid, "Esterabad", s. 132-139.

43 Celaleddin Yezdî, age., s. 233.

44 Ele geçirilen ganimetler 7 bin koyun, 3.500 deve, 700 at ve çok miktarda değerli maldır. Celaleddin Yezdî, age., s. 239. 
Şiî ailelerin yanlarına yerleştirilerek onların Şia mezhebine geçişleri kolaylaştırılmiştır ${ }^{45}$.

Şah Abbas'ın Hazar ötesine müdahalelerinden bir diğeri 1015/1606-1607 tarihinde vuku bulmuştur. İsyan Deşt-i Gürgen bölgesi ve Derun havalisinde gerçekleşmiştir. Bölge valisi Yusuf Han yakalandığı bir hastalık yüzünden zayıf düşmüştür. Onun ölüm döşeğinde yatmasını firsata çeviren Türkmenler isyan etmişler, civar bölgelerdeki at ve çeşitli hayvan sürülerine el koymuşlar ve bölge sakinlerinin mallarını yağmalamışlardır ${ }^{46}$.

45 Münşî bu esaret uygulamasını yıllarca Osmanlı'nın Tebriz'deki seyyid çocuklarını ve Özbeklerin Meşhed'de İmam Musa Kasım'ın soyundan eşraf, âlim, zahit, asker ve sivil halkın çocuklarının esir edilip uzak diyarlarda satılmasının rövanşı olarak değerlendirmiştir. Müellife göre Oklu ve Göklen halkı Müslümanlıkla isimden başka bağları olmayan imansız topluluklar olmasına rağmen Esterâbâd valileri Şah Abbas'ın emriyle Türkmen esirlere köle muamelesinde bulunmamışlardır. Esir kadın ve çocuklar iman sahibi Şiîlerin yanlarına yerleştirilerek onların hak mezhep yoluna girmeleri sağlanmıştır. Böylece devlet eliyle Türkmenlere büyük bir iyilik yapılmıştır. Münşî, age., C II, s. 1014-1015; Münşî-yi Türkmen, age., II. Cilt 1. Kitap 1-2-3. Kısımlar, s. 322. Münşı̂nin Osmanlı'nın İran esir politikasına yönelik iddiaları kısmen doğru olmakla birlikte yanlış yönlendirmeler de söz konusudur. Osmanlı Sultanı I. Selim, Safevî ile savaş hazırlıkları yaptı̆̆ı sırada muharebe alanlarında İran tebaasının esir edilmesine dair fetva hazırlatmıştır. Gerekçe olarak da Safevîler'in Râfizî oldukları ve sahabeye kötü söz söyledikleri öne sürülmüştür. Kanuni Sultan Süleyman zamanında ise Şeyhülislamlar vasıtasıyla Safeviler'in köle olarak alınıp satılabileceği hükmü verilmiştir. M. Tuğluca ve Ü. Küçük bu hüküm doğrultusunda 1723-1736 yılları arasında cereyan eden Osmanlı-Safevî savaşlarında Osmanlı kuvvetlerinin Râfızîleri ve küfür sahiplerini esir ettikleri bilgisini aktarırlar. Ancak bu bilginin yer aldığı Mühimme kayıtlarında Safevî tebaası olup Ehl-i sünnet halktan hatta seyyid ailelere mensup kadın, erkek ve çocuklardan da esir alındığını bildiren açıklamalara rastlamışlardır. Muhtemelen daha önceki yıllarda şer‘i hükümlere aykırı bu gibi muamelelerin gözlemlenmesi üzerine Osmanl, Ehl-i Sünnetten olanların, Sahâbeye küfretmeyenlerin, Râfıziliğine dair delil gösterilemeyenlerin esir alınmasını ve köle olarak satılmasını yine bir fetva ile yasaklamıştır. Bu yasağa rağmen üzücü hadiselerin yaşanmasına sebep olanların ise karıșıklıktan faydalanan "bozguncular" olduğu bildirilmiştir. Şu durumda Münşı̂’nin Osmanlı'nın İran esir politikası olarak verdiği bilgiler esasında münferit hadiseler olup birkaç kendini bilmezin ya da savaş halini firsata çeviren bozguncuların yasağı çiğneyen davranışları olarak ifade edilebilir. Murat Tuğluca ve Ülkü Küçük, "Osmanlı Devleti’nde Savaş Esirlerinin İadesi: 1736 Osmanlı-İran Anlaşması'na Göre Acem Esirlerin Teslimi Meselesi”, Osmanlida Siyaset ve Diplomasi, Ed. Mehmet Yaşar Ertaş vd., Mahya yay., İstanbul 2016, s. 61-62; Münşînnin Esterâbâd'daki Türkmen halkın Müslüman kimliğinden uzak olduğu tanımlaması da sorunludur. Tamamen resmi tarih yazıcılığı görevinden kaynaklı öznel bir bakışın yansımasıdır. Safevî Devleti'nde şahın aynı zamanda dini önder olduğu algısı ona karşı başlatılan tüm isyanları meşruiyet zemininden koparmakta ve dine aykırı bir tavır olarak düşündürmektedir. Bu nedenle Münşî için Sayın Hanî Türkmenlerinin Müslüman olmasının bir değeri yoktur. Ona göre Sayın Hanî Türkmenlerinin Şiî olup şaha sadakatle bağlı olmaları onları gerçek Müslüman yapacaktır.

46 Müellif, Sayın Hanîler’in yerleşik halka zulmettiklerini belirtmek için onları har ateşlerde yaktıklarını beyan etmiştir. Ancak bu ifade gerçeği yansıtmamaktadır. Çünkü Türkmenlerin esas maksadı mallarına vergi adı altında el koyan Esterâbâd yöneticilerinin baskısından kurtulmak ve yaşadıkları ekonomik buhranı yağmalarla telafi etmektir. Bistamî, age., s. 35-36; Celaleddin Yezdî’den öğrendiğimiz kadarıyla Şah Abbas'ın itimat ettiği Esterâbâd valisi Yusuf Han, Muharrem 
Yusuf Han iyileşemeyince hava ve su değişikliği gerekçesiyle Bistam’a gitmiştir. Bu süreçte Deşt-i Gürgen'deki yönetim boşluğundan haberdar olan Oklu lideri Karihan ve emrindeki Türkmenlerin bölge halkına dönük saldırıları büyük artış göstermiştir. Türkmenler, Gürgen nehri üzerinde yer alan ve Safevî yönetiminin garnizon birliklerinden müteşekkil Mübarekâbâd kalesi civarına saldırmışlardır. Burayı muhafaza etmekle sorumlu askerleri öldürmüşlerdir. Kaleye iki fersah uzaklıktaki Deveci mevkiine yerleşip üç gün kadar dinlenmişlerdir. Böylece güçlerini toplayıp kuşatmaya kaldıkları yerden devam edebilmişlerdir. Mübarekâbâd komutanı Pir Ali Bey-i Pürnek, Kaçar boyuna mensup askeri birliklerle kaleyi savunmuş ancak kale içini muhafaza etmenin dışında bir başarı gösterememiştir ${ }^{47}$.

Bu gelişmeler üzerine Şah Abbas, Ramazan 1015/Aralık 1606-Ocak 1607 tarihinde hassa birliğinde görevli Feridun Han-ı Çerkes’i Safevî birliğinin başında Deşt-i Gürgen'e göndermiş ve isyancı Türkmenlerin cezalandırılmasını emretmiştir ${ }^{48}$. Yusuf Han'ı ise başkent İsfahan'a çağırmıştır ${ }^{49}$. Bu görevlendirme esasında Şah Abbas'ın ülke genelinde uyguladığı Kızılbaşların tasfiye politikasının da bir gereğidir. Görüldügüu üzere Safevî hükümdarı sadece Hazar Denizi’nin doğusunda yaşayan ve devlet otoritesini tanımayan Sayın Hanî Türkmenleriyle uğraşmamaktadır. Aynı zamanda atası Şah Tahmasb’ın vefatından itibaren hanedanı kıskaca alan, saraya baskınlar düzenleyen, padişahları tehdit eden hatta beğenmediği hanedan mensubunu suikastlarla katleden devletin kurucu unsuru Kızılbaş Türkmenlerin gücünü de kırmak istemektedir. Kısaca "kukla padişah" olmayı reddetmektedir ${ }^{50}$.

1012/Haziran-Temmuz 1603 tarihinde şahın isteği üzere Göklen ilinden Kılıç Han’ın kızı, Karahan'ın yeğeni olan Türkmen kızına talip olmuştur. Karahan evliliği onaylamış ve nikâh sonrası bu Türkmen kızı Esterâbâd'a Safevî valisinin eşi olarak gitmiştir. Şahın böyle bir evliliği istemesindeki sebep bölgenin güçlü Türkmen ili Göklenler ile yakın münasebetler kurmak, Göklenler’in diğer Türkmen boylarıyla ilişkilerini bozmak ve isyanına engel olmak şeklinde değerlendirilebilir. Ancak 1015/1606-1607 yılı olayları, evliliğin beklenilen sonucu yaratmadığına apaçık kanıttır. Celaleddin Yezdî, age., s.240.

47 Bistamî, age., s. 36.

48 Bistamî, age., s. 35 .

49 Bistamî, age., s. 38.

50 Şah Abbas esasında Kızılbaş Türkmen Beylerinin yetki aşımından en fazla zarar gören kişidir. Amcası Şah II. İsmail ile annesi Hayrunnisa Begüm (Mehdi Ulya) onlar tarafindan öldürülmüş, babası M. Hüdabende Kızılbaş'ın baskısına boyun eğmek zorunda kalmış, kendisi de Herat valiliği sırasında Horasan'daki Kızılbaş Türkmen boyları arasındaki mücadelenin tam ortasında kalmıştır. Bu nedenle tahta çıkışından itibaren kendisine sadık bir askeri birlik kurmuş ve adına Şahsevenler demiştir. Bu sınıf Şah Abbas'ın isteğiyle bürokraside Kızılbaş beylerin yerlerini almiştır. Roemer, agm., s. 250-268. 
Deşt-i Gürgen seferini Mâzenderan şehrinden yöneten Feridun Han, bölgede kontrolü sağlamak adına sıkı önlemler almış Mübarekâbâd kalesinden Esterâbâd şehir merkezine kadar her yerde silahlı birlikleri konuşlandırmıştır. Feridun Han'ın Mâzenderan'da olduğunu duyan Türkmen ağaları ve aksakallar onunla görüşmek ve isyancılardan duydukları rahatsızlıkları bildirmek üzere yola çıkmışlardır. Bu gelen heyet Oklular'dan Karihan ve Göklenler'den Karahan'ın Mübarekâbâd kalesini kuşatacaklarını bildirmişlerdir. Feridun Han isyancı Türkmenleri durdurmak üzere kale yakınlarındaki Yesaki (يساقى) mevkiine yerleşmiştir ${ }^{51}$.

İsyancılar Abeskun (آبسكون)'a ulaştığında Yesaki mevkiindeki Safevî ordusu onlar üzerine yürümüş ve isyancıları mağlup etmiştir. Zafer sırasında diğger bir grup Derun'u ele geçirmiştir. Son askeri hareket Mübarekâbâd kalesine gerçekleştirilmiş ve bölgede sükûnet sağlanmıştır ${ }^{52}$. Feridun Han bu başarılarından dolayı Deşt-i Gürgen'in yani Esterâbâd'ın Emirü'l-Umerası olarak atanmıştır ve görevini 1030/1620-1621 yılına kadar aralıksız sürdürecektir ${ }^{53}$.

\section{a. Feridun Han'ın Sayın Hanî Türkmenleri Üzerine Askeri Müdahaleleri}

Feridun Han, beylerbeyi olarak atanmasından ölüm yılına kadar sürekli küçüklü büyüklü Türkmen isyanlarını bastırmakla meşgul olmuştur. Safevîler düzenledikleri her seferle direnişi bastırmışlar fakat bu durum yeni isyanların ortaya çıkmasını engellememiştir. 1606 yılında Safevîler'in Esterâbâd'da kontrolü sağlamalarına müteakip ilk çatışma Deşt-i Kıpçak’taki Divan ve Kemal vadilerinde gerçekleşmiştir. Bistamî’ye göre dikenlerle ve çalı çırpıyla kaplı, yaşamın güçlükle sağlandığı, yolu beli olmayan bu çöl arazi devlete muhalif Türkmenlerin asıl vatanıdır $^{54}$. Feridun Han, Derun hâkimi Uğurlu Sultan ve Tevekkül Han-ı Giraylı ile güçlerini birleştirmiş ${ }^{55}$ ve Esterâbâd'a 11 günlük mesafede bulunan Divan ve Kemal vadilerine doğru yürümüştür. Bistamî’nin kıyamet ve tufan ile özdeşleştirdiği

51 Bu noktada Bistamî savaşta Feridun Han'ın daha avantajlı olduğunu belirtmek adına şu sözleri nakletmektedir. Sanki Allah u zü'l-celâl bu memleketin kaderini Yüce Han'a yazmıstı ve bu kasabanın fetih anahtarm onun iktidarna bırakmıstı. Bistamî, age., s. 38-41.

52 Yesaki’de 350 kadar isyancının başı gövdesinden ayrılmıştır. Bistamı̂’nin aktardığı üzere Feridun Han daha sonra bu kelleleri zaferini müjdelemek için huzuruna çıktığı Şah Abbas'ın ayaklarının önüne bırakmıştır. Bistamî, age., s. 41-42.

53 Bistamî, age., s. 9, 44.

54 Bistamî, age., s. 59, 60-61.

55 Bistamî, age., s. 59-60. 
savaşın $^{56}$ galibi Feridun Han idaresindeki Safeviler'dir. Türkmenlerin önde gelen beyleri de dâhil 780 kişi hayatını kaybetmiş, mallarına el konulmuş ${ }^{57}$ kız ve erkek çocukları esir düşmüştür ${ }^{58}$.

Feridun Han'ın Deşt-i Kıpçak üzerine bir sonraki seferi Save Dağı (صعوه داغى) mevkiine gerçekleştirilmiştir. Bistamî’nin dördüncü sefer olarak aktardığı ve 1019/1610-1611 yllına işaret ettiğ $i^{59}$ bu askeri harekâtın gerekçesi Save Dağı etrafinda yaşayan halkın Bistamî’nin ifadesiyle açgözlü hırsızlar gibi ellerindeki at ve sığır ile yetinmeyip isyan bayrağını kaldırmalarıdır. Göklen ili liderleri Kılıç Bey, Şah Nazar Bey ile Karahan Sultan'dır ${ }^{60}$. Taraflar arasında şiddetli bir harp vuku bulmuş ${ }^{61}$ ve savaşın bilançosu Türkmenler için ağır olmuştur. Yaklaşık 700 Türkmen savaş̧̧ı öldürülmüş, çok sayıda esir ve ganimetle birlikte Türkmen kalesi Safeviler'in eline geçmiştir ${ }^{62}$. dir;

Kıpçaklıları biçare ettiklerinde

Onları katletmek ve yağmalamak için hücuma geçtiklerinde

Cümle kızların billur gibi bedenleri

Yağmacıların eline geçti

Emirlerinin hepsi esir düştü.

Onların endişesi ok yarasıyla söndürülüp

Mızrakla göğüslerinde yara açlldı.

Her biri kendi ölümünün matemindeydi.

Bistamî, age., s. 67-68.

Bistamî, age., s. 69.

Bistamî, age., s. 70.

Yazar savaşın seyrini şu şekilde şiirleştirmiş̧ir.

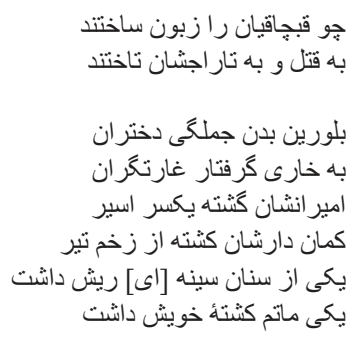

Kıpçakların yolunu kestiler.

Ateş ve duman gibi coşkuyla savaştılar

Düşmanlık kılıcıyla kan da akıttılar

Savaş sözünü meydana düşürdüler

Devrin mertlerini namertlerden ayırdılar.

Bistamî, age., s. 71-72.

62

O kavmi dağıttılar

Hepsinin kanını akıttılar

Kıpçaklılara mağlubiyet ulaştı

Onlardan birçoğunun ellerini ve ayaklarını kestiler
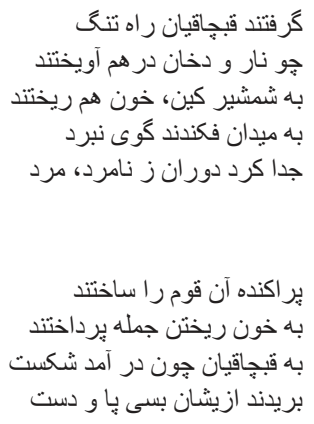
Feridun Han'ın bölgeye gerçekleştireceği altıncı seferin sebebi Şah Nazar Bey ve önde gelen on beyler ${ }^{63}$ idaresindeki Türkmenlerin büyük başkaldırısıdır. Bistamî’ye göre bu olayda Türkmenlerin hırsız ve haydut nitelikleri yönetime duydukları kin ve düşmanlıkla birleşmiş ve büyük bir isyan patlak vermiştir ${ }^{64}$. Feridun Han, 1200 kişilik Safevî birliğiyle derhal Deşt-i Kıpçak’a yönelmiştir. Şah Nazar Bey ise 2500 kişilik süvari ve piyade birliğiyle iki menzil öteden Kıpçak bozkırının etrafını sarmıştır ${ }^{65} .7$ gün süren saldırıların ardından iki ordu savaş meydanında karşı karşıya gelmiş ${ }^{66}$ ve Safevîler savaşın galibi olmuştur ${ }^{67}$.

Feridun Han'ın sekizinci seferi Göklenler'den bir grup hırsızın Fenderesk mevkiinde iki kişiyi öldürmesi ve binek hayvanlarını gasp etmesi üzerine yaşanmıştır. Safevî güçleri Göklenler üzerine yürümüş ve onları mağlup etmiştir. 247 Türkmeni öldürmüş, çok sayıda esir ve ganimet ele geçirmişlerdir. Karahan Sultan'ın erkek kardeşi Tohmak Bey, annesi ve akrabaları da Safevîler'e esir düşenler arasındadir ${ }^{68}$.

Birinin başını gövdesinden kesip ayırdılar

Birinin elini ve belini kırdılar

Cesur göçebeler kaçtılar

Keskin rüzgârın zararından çer çöp gibi

Dünya siyah tozla karardı

Çöle kaçmaya başladılar

Kahramanlar tüm ormanı temizlediler

Savaş meydanından kovdular.

Bistamî, age., s. 73.

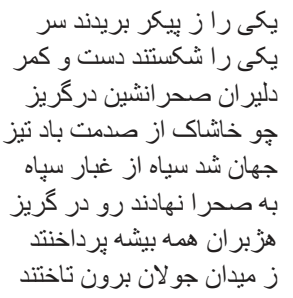

يكى راز يُ بكر بريدند سر

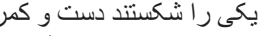
دلير ان صحر انشين دركريز

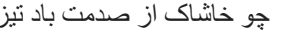
جهان شد سياه از غبار سباه بانه صحر انهادند رو در كريز ز ميدان جو لان برون تاختند

63 On Beyi rütbesi Altın Orda devletinde ordu sisteminin bir parçası olarak karşımıza çıkmaktadır. Sayın Han (Batu Han) idaresinde kurulan bu devletin ordu yapısı Kadim Türk teşkilatında olduğu gibi Onlu kademelerden meydana getirilmiştir. Buna göre en başta hakan onun altında hükümdarın çocuklarının görevlendirildiği Sağ ve Sol Kol Oğlanları yer almaktadır. Ordudaki görevliler asker sayısına bağlı olarak Tümen-Beyi, Bin-Beyi, Yüz-Beyi ve On-Beyi unvanlarıyla kendilerine bağlı askerlerin sevk ve idaresinden sorumlu tutulmuşlardır. Mustafa Kafalı, Altın Orda Hanlığmin Kuruluş ve Tükseliş Devirleri, İstanbul Üniversitesi Edebiyat Fakültesi yay., İstanbul 1976, s. 126-130; Nasır Afşar-fer ise kelimenin İlhî (اليخى) ya da Oymak (اويماق) olarak açıklanabileceğini söylemiştir. Afşar-fer, agm., s. 255.

64 Bistamî, age., s. 79.

65 Bistamî, age., s. 80.

66 Müellif savaşın başladığı anı

Devlet kuşu yükselmiş ve zafer bayraklan kaldrnlmuşt.

هماى هايون فال بلند كرديد و رايات ظظفر آيات بر أفراشتند.

sözüyle betimler. Bistamî, age., s. 81.

67 Safevîler savaş meydanında 345 Göklen’in kafasını kesmiş ve 23 kişiyi sağ ele geçirmişlerdir. Bistamî, age., s. 82-83.

68 Feridun Han, Pir Ali Bey-i Pürnek ve İmani Bey-i Kaçar'ı serdar tayin edip 800 askerle Göklen- 
Göklenler'in sonraki isyanı bir grup on beyinin katılımıyla Karahan Sultan'ın oğlu İsmail Bey ve torunu Timur Bey'in idaresinde gerçekleştirilmiştir ${ }^{69}$. Feridun Han, Şah Abbas'ın onayıyla Deşt-i Kupçak'a doğru harekete geçerken İsmail Bey de 1300 kadar Türkmen ile Safevî ordusunu karşılamışıı ${ }^{70}$. Her iki tarafin sonuna kadar direndiği, kılıç, ok-yay ve fitilli tüfekle birbirlerine meydan okudukları bu savaş Göklenler’in mağlubiyeti ve Feridun Han’ın bölgede kontrolü sağlamasıyla sonuçlanmışıı ${ }^{71}$.

Feridun Han'ın onuncu seferi Karahan Sultan'ın erkek kardeşi Şah Nazar Bey'in yakalanması amaciyla Dede Kümbedî (دون كنبدى) ve Bayram Yolu (بيرام) (يولو üzerinden gerçekleştirilmiştir. İlk hedef Göklenler'in 7.000 haneden oluşan Dodurga grubudur ${ }^{72}$. Seferin başladığı 14. günün gecesi Safevî birlikleri, Dodurga Türkmenlerine ulaşmışlardır ${ }^{73}$. Şah Nazar Bey yanındaki 1200 Türkmen ile savunmaya geçmiştir ${ }^{74}$. Feridun Han’ın emri üzere 400 kişiden oluşan öncü birlik sabah saatlerinde saldırıya geçmiş pek çok Türkmen öldürülürken az sayıda bir grup kaçmayı başarmıştır ${ }^{75}$. Bistamî ölen Türkmenlerin sayısını 622 olarak açıklamıştır. Bunun yanı sıra Safevî ordusundaki kayıplara da değinen müellifin bir rakam telaffuz etmekten kaçındığı görülmektedir. Safevî askerlerinin ölümlerine sebep olarak da tarafların içinde bulundukları savaş haline değil o esnada yaşanan hava sıcaklıklarına işaret etmiştir. Müellif hava sıcaklığının çöl sıcaklıkları hissiyatı

ler’in üzerine göndermiştir. Göklenler de çok kalabalık süvari ve piyade birliklerle Safevî ordusuna karşıllık vermişlerdir. Bistamî, age., s. 89-90.

69 Dokuzuncu fetih olarak aktardığı bu hadisede Bistamî sebebi bilinmeyen bir şekilde önce İsmail Bey'i övmüş akabinde isyanına herhangi bir mana veremediğini şu sözlerle beyan etmiş̧tir.

Akranlar arasinda cömertlĭgi ve yürekliliğgyle eşi benzeri bulunmayan Ísmail Bey, sürekli manasız yere kavgaya giriyordu.

اسمعيل بيح در جلادت و فتوت ميان اقران عديل و نظير نداشت، همواره كردن به دعوى بى معنى بر مى افر اشت

Bistamî, age., s. 91.

70 Feridun Han’ın birliğinde Avcıbaşı (Şikar-başı) Ali Han Bey-i Kaçar, Eşikağası Başı Saruhan Bey, Sofracı Tahmasb Bey ve İbrahim Kulu Bey-i Pürnek de vardır ve onların emrindeki gaziler ile gulâmlar öncü birlik olarak tayin edilmişlerdir. Bistamî, age., s. 92, 94.

71 Bu savaşta Göklen boyu 270 kişilik bir kayıp vermiştir. Ayrıca İsmail Bey, oğlu Timur Bey ve On Beylerden 14 kişi Safevî askerlerince ele geçirilmiştir. Geriye kalanlar ise kaçmayı başarmışlardır. Bistamî, age., s. 92, 96-97.

72 Bistamî, age., s. 99-100.

73 Bistamî, age., s. 101.

74 Bistamî, age., s. 103.

75 Bistamî, age., s. 104-105.

Belleten, Ağustos 2021, Cilt: 85/Sayı: 303; 507-544 
yarattığını ve Safevî askerlerinin susuzluktan öldüklerini beyan etmiştir ${ }^{76}$. Bundan önceki karşlaşmalarda olduğu gibi Safevîler, Türkmenleri yağmalamış, kadın ve çocukları esir almışlardır. Esir düşenler arasında Şah Nazar Bey de vardır ${ }^{77}$.

İlhan Dağı eteklerinde yaşayan Dodurga ve Dağlı Türkmenlerinin Giraylı ve Derun taraflarına saldırmaları at ve diğer hayvan sürülerine el koymaları üzerine Feridun Han on birinci Türkmen seferini başlatmıştır ${ }^{78}$. Feridun Han, Uğurlu Sultan ile Tevekkül Han'ın da aralarında bulunduğu bölgedeki tüm emirleri isyancılarla mücadelede görevlendirmiş ${ }^{79}$ kendisi de 700 askerle Dodurgalılar'ın üzerine yürümüştür. Savaşın bilançosu Türkmenler için oldukça ağır olmuştur. Yaklaşık 500 Dodurgalı öldürülmüş, 150 hane halkı esir edilip yağmalanmıştır. Üstelik Deşt-i Kıpçak sınırlarındaki İlhan Dağı etekleri Feridun Han’ın idaresine geçmiştir ${ }^{80}$.

Feridun Han on ikinci seferinde Oklu ve Ayağlu (اياغلو) Türkmenlerini hedef almıştır. Askeri müdahalenin gerekçesi Bistamî’nin ifadesiyle yaklaşık 1500 hanelik Oklu'nun Safevîler'e itaat edip, kılıç korkusuyla Şia mezhebine dönüp yurtlarında rahat ve huzur içerisinde yaşarken bir anda kulluğu terk etmeleridir. Yukarıdaki bilgiden de anlaşlacağı üzere Sayın Hanî Türkmenleri Şah Abbas döneminde dahi İslam'ın Sünni mezhebine bağlılıklarını sürdürmektedirler. Yönetimin baskısıyla kimi zaman mezhep değişikliğine giderek maruz kaldıkları kötü muameleden kurtulsalar da değişimin sürdürülebilir olmadığı ortadadır. Bu nedenle halk ile yönetim arasındaki anlaşmazlıklar bir türlü son bulmamıştır. Safevî-Türkmen çatışmaları ekonomik sıkıntıların yanı sıra mezhep farklılı̆̆ının etkisiyle sürekli şiddetlenmiştir. Nitekim Esterâbâd yönetimi, Karihan idaresindeki Okluların isyanını durdurmak için harekete geçmiştir. Bu sırada Ayağlu (اياغلو) Türkmenleri de başkaldırmıştır. Safevî birlikleri önce Ayağlu ayaklanmasını bastırmış akabinde

76 Bistamî, age., s. 106.

77 Bu fetih dönüşünde daha öncekilerden farklı bir gelişme yaşanmış Safevî birlikleri Esterâbâd'a dönüş yolunda Etrek nehrinden geçmekte zorluk yaşayınca çok sayıda ganimeti ve esiri arkalarında bırakmak zorunda kalmışlardır. Bistamî, age., s. 108.

78 Bistamî, age., s. 111.

79 Bistamî, age., s. 112.

80 Bistamî, age., s. 115-116; Celaleddin Yezdî, olayı teferruatlı anlatmamakla birlikte Feridun Han'ın Göklen seferini ve bu sefer sonucunda 500 Türkmen'in öldürüldüğü bilgisini teyit etmektedir. Ayrıca Bistamî'den farklı olarak 4.000 tümen altın ve gümüşten ibaret ganimetin 1 Recep 1020/9 Eylül 1611 tarihinde ele geçirilen esirlerle birlikte şahın sarayına gönderildiğini söylemektedir. Celaleddin Yezdî, age., 426. 
Karihan’ın bulunduğu Mübarekâbâd kalesini kuşatmışlardır. İsyancılar bu kuşatmaya direnemeyince gizlice kaleyi terk etmişlerdir ${ }^{81}$. Oklu yurdu yakınında 2000 Türkmen ile Safevî birlikleri karşı karşıya gelmiş̧2 ve Türkmenlerden 700 kişi öldürülmüştür ${ }^{83}$.

Feridun Han'ın otoritesine en fazla karşı çıkan Türkmen boyu Göklenler'dir. Dodurga yurdu olarak bilinen Dede Kümbedîn ${ }^{84}$ ve Elce ya da Alaca Dağı (الجه (داغى yeniden isyanlara sahne olunca on üçüncü sefer buralara gerçekleştirilmiştir.

81 Bistamî, Ayağlu Türkmenlerini dinsiz topluluklar olarak tanıtır ve içinde bulundukları acizlikten ve yalnızlıktan kaynaklanan nefretlerinin Karihan'ın isyanını daha da büyüttüğünü söyler. Bistamî, age., s.121.

82 Bistamî, age., s. 122.

83 Bistamî, age., s. 123, 125. İsyancılar için Kıpçaklılar ismini kullanan müellif boy üyelerinden hiçbirinin savaşçı kabiliyette olmadığı iddiasını şu şiiriyle beyan etmiştir;

Ben Kıpçaklıların savaşından ne söyleyeyim

$\mathrm{Ki}$ onu anlatacak hiçbir yol yoktu

Savaş sırasında cesaret öyle bir noktadaydı ki

Avrupalı'nın tüfeğini yok saydılar

Onlardan biri gürzü ayağa attı

Düşsün üç kişiye cevap versin

Bir bakışta oku attıklarında

$\mathrm{O}$ anda baş göğüste kalmasın

Tüfek ağzı aydınlı̆̆ı engellesin

Yüz çevirmekten utansınlar

Savaşçı bir adam dünyaya yeterliydi

O kavimden hiç kimse öyle birini görmedi.

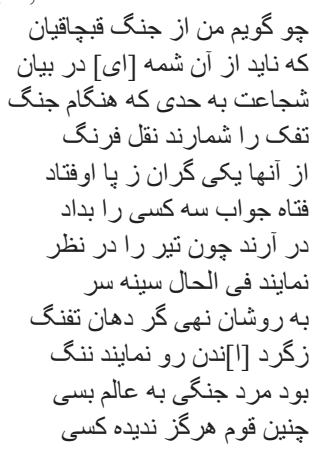

Bistamî, age., s. 126-127.

84 Feridun Han Uğurlu Sultan, Tevekkül Han ve Safir Kulu Sultan-ı Çegeni’yi Dede Kümbedî’deki Dodurgalılar üzerine göndermiştir. Müellif vuku bulan savaşı da şöyle nakletmiştir.

O gafil kavim üzerine seher vakti hücum ettiler

Öldürülenlerden bir grubu yaktılar

Kınlarından savaş kılıçlarını çektiler

Katliam sesini yaydılar

Genç ve yaşlılardan o taifenin erkeklerinin tamamını

Oklara hedef yaptlar

O topluluğun az sayıdaki kadın ve kızlarını

Bedenindeki gümüş sinesiyle hepsinin nazı

Âşık gençlerin gönüllerini çeliyordu

Onların özelliklerinden gönül beni terk etti

Tamamı figan ettiği sırada

Cesaret sahipleri geldiler ve esir ettiler

بر آن قوم غافل سحر تاختند يكى بشته از كثتكان ساختند كثيدند تيغ ستيز از نيام

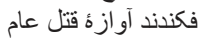

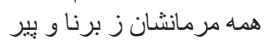

هدف وار كثنتند آماج تير

زن و دختران اندر آن انجمن

همه ناز بِّتان سيمين بدان

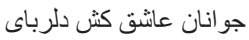

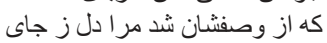

جونى جملكى در فغان آمدند

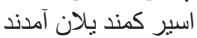

Bistamî, age., s. 129-130. 
Türkmenler mağlup edilirken ${ }^{85}$ reisleri Karihan Sultan beraberindeki on beylerle birlikte kaçmayı başarmıştır ${ }^{86}$.

Bundan sonraki süreçte Feridun Han'ın başını ağrıtan Türkmen boyları Oklu Karamanga (اوخلو قرامنكا) ${ }^{87}$ ile Eymür, Oklu, Acillu, Hızır Eli, Salur, Deveci, Kızılcalı ve Dodurgalılar'ın toplu isyanları olmuştur ${ }^{88}$. Art arda düzenlenen seferlerle Türkmenler mağlup düşmüş ve çok sayıda kayıp vermişlerdir ${ }^{89}$. Feridun Han Türkmen isyanlarının bir daha yaşanmaması için öldürülen Türkmenlerin başlarını atların ayakları altına attırmıs, esirleri de Safevî ülkesinin dört bir yanında satışa çıkartmıştır. Feridun Han bu defa Gürgen ülkesinden hemen ayrılma niyetinde değildir. Türkmen yurdunda güçlü bir yönetim tesis ederek gelecekte yaşanacak isyanların tamamen önünü almak istemektedir. Bu sebeple bölgeyi mamur hale getirmek için çalışmış, tayin ettiği yöneticilerden halka adaletle hükmetmelerini istemiştir. Bistamî’ye göre bu çalışmalar olumlu sonuç vermiştir ${ }^{90}$.

Ancak Feridun Han'ın yumuşak güç politikasına geçişi ve halkın sorunlarına eğilme çabaları Türkmen isyanlarına son vermemiştir. On sekizinci sefer at hırsızlığı yapan Kızılca Türkmenleri üzerine gerçekleştirilmiştir. Kızılca kalesi kuşatılmış ${ }^{91}$

85 Bistamî Safevîler'in, Dede Kümbedî yolu üzerindeki 220 haneli Dodurgalı Türkmen'den 380 kişiyi öldürdüklerini, hayatta kalanları esir ettiklerini ve mallarına el koyduklarını bildirmektedir. Ayrıca boyun kontrolünü sağlamak üzere Safevilli komutanlardan birinin bölgede görevlendirildiğini belirtmektedir. Bistamî, age., s. 131.

86 Safevîler 320 Türkmen’i öldürüp çok sayıda Türkmen’i esir almış ve mallarına el koymuşlardır. Safevî birlikleri zaferlerine müteakip Türkmen ülkesinde bir eğlence tertip etmişler, elde ettikleri ganimetleri aralarında paylaştırmışlardır. Buna göre esir ve ganimetin beşte birini oluşturan 800 çocuk esir ile çok sayıda at, deve, koyun ve diğer emtianın Emirü’l-Umera Feridun Han'a verilmesi gerekmektedir. Fakat Feridun Han kendi hissesine düşen ganimetin de askerlere dağıtılmasını istemiştir. Bistamî, age., s. 133-134.

87 Bistamî, Oklu Karamanga yurdunun Mübarekâbâd kalesine 17 fersah uzaklıkta bulunduğunu söylemektedir. Bistamî, age., s. 145-146.

88 Bistamî, age., s. 149-150.

89 On beşinci askeri müdahalede Oklu Karamanga'dan 1234 Türkmen'in başı kesilmiş, 800 hane Safeviler'in hükmü altına girmiştir. Bistamî, age., s. 147-148; Toplu isyanlar dolayısıla düzenlenen on altıncı seferde ise Türkmenler'den 3124 kişi hayatını kaybetmiştir. Bistamî, age., s. 149150 .

90 Bistamî Türkmen yurdunda güven ortamının sağlandığını, hukuk ve adaletin doğru işlediğini belirtmek için "Türkmenler keder, fitne ve her türlü zalimlikleri terk etmişlerdir." demektedir. Bistamî, age., s. 151-152.

91 Müellif önceki Kızılca seferlerine gönderme yaparak yeni saldırının Bakıyetü’s-Seyf-i Kızılca (بقية yani Kılıç artığı Kızılca üzerine gerçekleştirildiğini özellikle belirtmiştir. Bistamî, age., s. 157158. 
isyancılardan 274 kişi öldürülmüştür. Ayrıca Türkmenlerin yaşadığı nahiye ve köylere görevliler tayin edilmiş ve halka at ya da nakdî yardım başlatılmıştır. Bu sayede Kızılcalılar'ın yaşadığı ekonomik sıkıntılar bir nebze ortadan kaldırılabilmiştir $^{92}$. Feridun'un son iki seferi sırasıyla Damgan'daki Oklular ile Derun'daki Pelid Türkmenleri üzerinedir. Damgan'daki Safevî birlikleri ve destekçileri sağ salim kurtarılmış isyancı Oklular ise öldürülmüştür ${ }^{93}$. Mezid Bey idaresinde yaşayan Pelidler ise etrafi çöllerle kaplı heybetli kalelerinin sağladığı avantaja ek olarak iyi tahkimat ve savunma savaşıyla öncü Safevî birliklerine ciddi direnç göstermişlerdir ${ }^{94}$. Ancak Feridun Han'ın kaleye ulaşmasıyla bu dirençleri kırılmış ve 3.000 Türkmen kaçmıştır. Takipte olan Safevîler Yeha (يخه) denilen mevkide Türkmenlere ulaşarak saldırıya geçmişlerdir ${ }^{95}$. Savaş son bulduğunda Türkmenlerden 765 kişi öldürülmüş, çok sayıda Türkmen esir edilmiş ve sayısız ganimet ele geçirilmiştir. Feridun Han, Pelid Türkmenlerine ve o civarda yaşayan tüm sakinlere adaletle muamele edilmesini emretmiş akabinde yeni zaferini Şah Abbas'a iletmiştir ${ }^{96}$.

\section{b. Sayın Hanî Türkmenleriyle Uzlaşma ve Barış Süreçleri}

Safevîler'in 1015/1606-1607 yılında Esterâbâd'ı kontrol altına almasına müteakip yaşanan ilk gelişme Evâhir-i Ramazan 1016/Ocak 1608 tarihinde vuku bulan

92 Bistamî, Feridun Han’ın bu icraatını cömertlik göstermesi, adil hükümleri yürürlüğe koyması ve bölgede iyiliği esas kılması şeklinde değerlendirmiştir. Bistamî, age., s. 159-160.

93 Safevî emiri Ahmed Afşar, Damgan'da çıkan isyan üzere Feridun Han'a başvurmuştur. Bistamî bu kişi için Ahmed Afşar-1 Oklu-penâh (احمد افثار اوخلو بِناه) yani Okluların koruyucusu Ahmed Afşar unvanını kullanmıştır. Buradan hareketle Ahmed Afşar'ın Oklu Türkmenleri arasında istikrarı sağlamakla görevlendirilmiş olduğu anlaşılmaktadır. Feridun Han aldığı yardım çağrısı üzere Damgan'a ulaşmış Ahmed Afşar ve onunla birlikte hareket eden Okluları şehirden çıkarmıştır. Bistamî, age., s. 161-162.

94 Safevîler'in Pelid Türkmenleri üzerine seferi yaz aylarında gerçekleştirilmiştir. Bistamî, güneşin yakıcı sıcağı altında çölü aşmak durumunda olan Feridun Han'ın hem askerlerinin hem de yük hayvanlarının susuzluktan kimi zaman yere yığıldığını söylemiştir. Böylece Derun seferinin Safevîler nezdindeki zorluğunu gözler önüne sermiştir. Bistamî, age., s. 165-167.

95 Bistamî, Safevî askerlerinin tam bir itikatla fetih için savaştıklarını, borazan ve davul sesleriyle o çölde adeta zelzele yaşattıklarını, at kişnemelerinin ve yiğit naralarının tüm gökyüzünü kapladığını ifade etmiş̧ir. Bistamî, age., s. 168.

96 Bistamî bu zaferin en iyi sonuçlarından birini de Rahman Kulu Sultan'ın Safevî hükümetine sadakat ve kulluk yemini ederek ülkesine geri dönmesi olarak açıklamıştır. Rahman Kulu Sultan hakkında kaynaklarda fazla bilgi yoktur. İsmine eklenen Karabaş sıfatıyla Şah Abbas'ın önde gelen emirleri listesinde yer almakta, Çağatay boylan ve Sayn Hanî Türkmen/Yaka Oymak Emirleri grubu altında sıralanmaktadır. Herat'a tabi oymak emirlerinden Mir Şadi Sultan’ın oğlu olarak zikredilmektedir. Münşî, age., C III, s. 1809; Bistamî, Feridun Han'ın isyancılara adil ve şefkatli yaklaşımını Hz. Peygamber ve Oniki İmama duyduğu hürmete dayandırmıştır. Bistamî, age., s. 171-172.

Belleten, Ağustos 2021, Cilt: 85/Sayı: 303; 507-544 
görüşmelerdir. Celaleddin Yezdî, Şah Abbas'ın avlanmak amacıyla Mâzenderan'a doğru seyrüsefer yaptığı esnada Esterâbâd valisi Feridun Han'dan bir mektup aldığını söyler. Bu mektupta Sayın Hanî Türkmenlerinden Kılıç Han-ı Göklen’in kızını Feridun Han ile evlendirme, tasarrufundaki yerleri şahın hükmüne bırakma ve kendisinin de şaha itaat etme isteği yazılıdır. Şah Abbas bunun üzerine derhal Kılıç Han ile Karahan-ı Göklen’i huzuruna çağırmıştır. Karahan, Esterâbâd'dan şahın bulunduğu Meşhed şehrine doğru harekete geçmiştir. Huzura çıktığında şahın eteğini öpmüş ve hediyeler takdim etmiştir. Şah Abbas da Zilkade 1016/ Şubat-Mart 1608 tarihinde onu Göklenler'in lideri kabul edip Esterâbâd'a göndermiştir ${ }^{97}$. Böylece bölgede bir süreliğine sükûnet sağlanmıştır.

Bistamî’nin aynı olaya dair verdiği bilgiler ise farklıdır. Feridun Han Esterâbâd yöneticisi olduktan sonra bölgede huzuru sağlamak ve isyancı Türkmenleri zayıflatmak adına Göklen yöneticisi Karahan Sultan'a bölgeyi birlikte yönetmeyi teklif etmiştir. Böylece Deşt-i Gürgen, Safevî-Türkmen işbirliğiyle yönetilmeye başlanmıştır. Bir müddet sonra Feridun Han Göklenler’in isyan içerisinde olduğunu haber almıştır. Derhal halkın itibar ettiği adamlardan Seyyid Hasan Bey-i Kemune'yi gereken uyarıları yapmak üzere Türkmenler arasına göndermiştir. Ancak Göklenler, Safevî Devleti'ne itaat etme niyetinde olmadıklarını açık yüreklilikle dile getirmişlerdir ${ }^{98}$. Karahan'ın cevabı üzerine Feridun Han gazilerden, gulâmlardan ${ }^{99}$ ve tüfekçilerden oluşan 100 kişilik bir birlikle Deşt-i Kıpçak tarafina yönelmiştir.

Feridun Han, 1016/1608 yılının Nisan ayında bölgeye varmış ve 12.000 aileden oluşan Göklen obası yakınında ordugâhını kurmuştur. Bir gece Göklenler'den biri, bir Safevi askerinin okuyla öldürülmüş̧tür. Bu olay üzerine Türkmenler, Safevîler ile savaşmak yerine onları da kendi aralarına dâhil etmek için ikna yoluna başvurmuşlardır. Ancak Bistamî’ye göre Safevî askerleri Feridun Han'ın gazabından korktuklarından bu çağrıya kayıtsız kalmışlardır. Feridun Han teslim olmaları için

Celaleddin Yezdî, age., s. 333-334.

Bistamî, age., s. 47.

Münşî, gulâm kavramını şöyle açıklamaktadır. Dünyayn fetheden o padişah (Şah Abbas) devrinde bu zümrelerden pek çoğu İslam şerefini elde etmek saadetine nâil olduklarndan bu dergâhn kulluk şerefini de elde etmişlerdi. Bunlarn çoğu çocukluktan beri o hazretin merhameti sayesinde yetişip, terbiye görüp, büyümüsslerdi. Güzel ahlakla$n$, sadakatleri, istidat ve kabiliyetleri göz önünde tutularak emirlik, hanlık ve sultanlk makamına çıkanlmışlard. Müellif, Şah Abbas dönemi için toplamda 21 mühim emirin görev yaptığını söylemekte ve onlar arasından en seçkinlerin isimlerini zikretmektedir. Ancak bu listede Feridun Han-1 Çerkes'in ismi yer almamaktadır. Münşî̀-yi Türkmen, age., III. Cilt 1-2-3. Kısımlar, s. 219-220. 
Türkmenlere üç gün müddet tanımıştır. Bu süre zarfinda Göklenler’in önde gelenleri kendi aralarında kararlaştırdıkları üzere Feridun Han'dan bazı taleplerde bulunmuşlardır. Feridun Han bu tavrı küstahça bulduğundan Karahan Sultan’ı huzuruna çağırarak Göklen halkının asıl niyetini sormuştur ${ }^{100}$. Bu meselede Feridun Han, Karahan Sultan’a iki seçenek sunmuştur. Birincisi Karahan Sultan isyancı Göklenleri kontrol altına alacak ve Safevîler savaş alanından ayrılacaktır. İkincisi Türkmenler isyanda direnecekler ve Feridun Han beraberindeki askerlerle son nefesine kadar isyancılarla savaşacaktır. Feridun Han'ın ordugâhta kalacak askerler için de bir planı vardır. Mağlubiyet yaşanması halinde Safevî birlikleri yanlarındaki iki üç bin at, taç, kılıç, altın işlemeli hançer, zırh ve diğer eşyalarla birlikte Arab Han-1 Özbek'e sığınmak üzere Harezm tarafina gideceklerdir ${ }^{101}$.

Karahan Sultan, Safevîler ile savaşmakta çok istekliyken babası Kılıç Bey halkına sükûnet çağrısında bulunmuştur. Aynı anda Feridun Han'ın aldığı tedbirler de olumlu neticeler vermiş ve isyan sona erdirilmiştir ${ }^{102}$. Bistamî, Feridun Han'ın müzakereler sonrasında bölgede çeşitli kutlamalar tertip ettiğini söylemektedir. Bu kutlamanın sebeplerinden biri de anlaşıldığı kadarıyla Feridun Han’ın kendisine bölgeden bir gelin almasıdır. Gelinin kim olduğuyla ilgili müellif bir bilgi aktarmasa da yukarıda ifade edildiği üzere Yezdî, Kılıç Han-ı Göklen’in kızına işaret etmektedir ${ }^{103}$.

Tertip edilen düğün ziyafetinde Feridun Han'ın şarap içerek eğlenceye katıldığı1 ${ }^{104}$,

100 Müellif olayın geçtiği tarihi Nisan yağmurlarnnda (جون باران نيسان) şeklinde ifade eder. Kronoloji dikkate alındığında yılın 1016/1608 olması kuvvetle muhtemeldir. Bistamî, age., s. 48-50.

101 Bistamî, age., s. 51.

102 Bistamî, Feridun Han'ın bu başarısını Oniki İmam-ı Ma sumîn'in yardımına dayandırarak Feridun Han'ın zaferine ruhani bir boyut kazandırmıştır. Bistamî, age., s. 52-53.

103 Yazar düğün için tertip edilen ziyafet meclisini ise şöyle şiirleştirmiştir.

Bir düğün meclisi düzenlediler

Sakiden kırmızı istediler

Gençler ve ihtiyarlar baş başa oturdular

Kadın ve erkek birbirlerinin yanında

Her tarafta eğlence başladı

Her tarafta neşeli müzik çalındı

O meclisin etrafinda kızlar

Hepsi ayak vuranlar hepsi kadınlar gibi

Hepsi ay yüzlü gümüş tenli

Bistamî, age., s. 53-54.

104 Bistamî, age., s. 55.

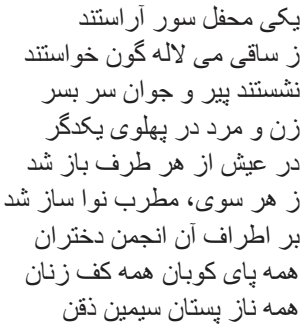

Belleten, Ağustos 2021, Cilt: 85/Say1: 303; 507-544 
isyancı Türkmen liderlerden Kılıç Bey, Karahan Sultan, Hançer Sultan ve Rahman Kulu Sultan başta olmak bazı yerel beylerin de ona eşlik ettiği bilinmektedir. Eğlencenin son bulmasıyla Feridun Han, Kılıç Bey ile baş başa görüşmüş ve Deşt-i Kıpçak'tan ayrılmıştır ${ }^{105}$.

Feridun Han, Kılıç Bey ile görüşmesinde ona Safevî Şahına kulluğa devam etmesini ve Deşt-i Kıpçak’ta şahın şanını yüceltmesini buyurmuştur. Bu minvalde Şah'a itaati terk eden ve isyan yolunu seçen Hançer Sultan Alimengi'nin de kendilerine teslim edilmesini istemiştir. Kılıç Bey, Safevî birlikleriyle çatışmaya girmemek üzere bu teklifi kabul etmiştir. Nihayet Çopançuk (جويانجوق) mevkiinde Hançer Sultan Alimengi ele geçirilmiş ve şahın huzuruna çıkarılmak için başkent İsfahan'a gönderilmiştir ${ }^{106}$.

Uzlaşma teklifinin ilk olarak hangi taraftan geldiği kaynaklarda farklı yansıtılsa da hatta Yezdî, 1608 yılında cereyan etmiş bir Türkmen isyanından bahsetmemiş bulunsa da sonuçta tarafların barışçıl bir yolda buluştukları bilgisi ortaktır. Uzlaşmanın evlilik akdiyle garantiye alınma isteği de dikkat çekicidir.

Bir sonraki barış görüşmeleri Save Dağı'ndaki Safevî-Türkmen savaşına müteakip gerçekleşmiştir. Mağlup Türkmenler Feridun Han’ın huzuruna hediyeler eşliğinde bir heyet göndermişler ve vergi ödeme teklifinde bulunmuşlardır ${ }^{107}$. Feridun Han, Türkmenlerden gelen hediyeleri hatta Türkmenlerin Şah’a ödemeye razı oldukları at, altın ve hilatten oluşan vergi teklifini kabul etmemiştir. Deşt-i Kıpçak’taki Türkmenlerin sözlerine sadık kalmaları ve Safevî yönetimiyle iyi ilişkiler içerisinde olmaları koşuluyla boya bağlı tüm insanların kale etrafinda iskân etmelerine izin vermiştir. Şayet Türkmenler sözlerinde durmazlar ise o zaman Safevî birliklerinin tekrardan bölgeye hücum edeceğini ve sorumluların gereken cezayı alacaklarını bildirmiştir. Feridun Han elçilerle görüştükten sonra kendilerine hilat vererek geri dönmelerine müsaade etmiştir. Elçilerin getirdiği bu haberler Türkmenleri teskin etmediği gibi daha fazla korkuya kapılmalarına sebep olmuştur. Bunun üzerine

105 Bistamî, age., s. 56.

106 Bistamî, age., s. 57.

107

Kıpçaklılara iş zor geldiği için

جو آمد به قبجاقيان كار تنى آنق

Savaş meydanını terk ettiler

Tercihlerini sulhtan yana yapıp

Onlar tarafindan haracı kabul ettiler.

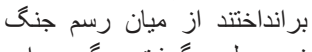

Bistamî, age., s. 75.

زر صلح بكرفت ديگر رواج رئن

نمودند ازيشان قبول خراج

Belleten, Ağustos 2021, Gilt: 85/Sayı: 303; 507-544 
Türkmenlerden on beyi unvanlı üç kişi çok sayıda at, deve ve koyun ile birlikte tekrardan Feridun Han'ın huzuruna çımış ve kendilerinin Safevî Devleti'ne bağlanmak hususunda istekli olduklarını bildirmişlerdir. Feridun Han'dan şefkat ve merhamet dilendikleri gibi ondan gelecek her türlü emre riayet edeceklerini de beyan etmişlerdir. Şayet talep edilirse boy ileri gelenlerinin kız ve erkek çocuklarının da Safevî valisinin hizmetine verileceğini ifade etmişlerdir. Bunun üzerine Feridun Han bölgedeki Seyyid Hasan Bey’i antlaşma yapmak üzere Deşt-i Kıpçak’a göndermiştir. Antlaşma gereği Safevî yerel yönetimi bölge halkından vergi tahsil edecek ve karşı taraf antlaşmayı bozmadığı müddetçe alınan kararlar yürürlükte kalacaktır ${ }^{108}$.

Seyyid Hasan Bey ve beraberindekiler sefaret göreviyle gerçekleştirdikleri bu ziyaret sırasında Türkmenlerden büyük saygı görmüşlerdir. Onlar bizzat on beyleri tarafından karşılanmışlardır. Dönüş yolunda Hasan Bey'e Deşt-i Kıpçak On beylerinden beş kişi refakat etmiştir. Ayrıca Türkmenler, Karahan Sultan’a ait ve o dönemde 50 deve satın alabilecek değerde bir at, çok sayıda deve, koyun, çadır ve koşum takımlarını da hediye olarak göndermişlerdir. Feridun Han, Türkmen on beylerine iyi muamele etmiş, onlara hilat giydirmiş ve Deşt-i Kipçak yönetimine atanan bir darugayla birlikte kendi ülkelerine gitmelerine müsaade etmiştir ${ }^{109}$. Esasında Bistamî isyancılarla Safevî yöneticileri arasındaki bu ziyaretleri ve karşlıklı uzlaşma çabalarını Feridun Han'ın beşinci seferi olarak aktarmıştır. Ancak bir önceki askeri müdahalenin Türkmenlerin direncini kırdığ ve sulha razı ettiği aşikârdır. Dolayısıyla bu bir sefer değil ateşkes sürecidir.

\section{c. Safevî- Sayın Hanî Türkmen Mücadelelerinde Diplomasi ve Taktik Savaşları}

Safevîli valilerin Türkmenlerle mücadelede tercih ettikleri yöntemlerden biri de siyasi komplolar düzenlemektir. Bu manada Feridun Han'ın Deşt-i Gürgen'e yönelik yedinci seferi askeri değil siyasi hamlesine örnektir. Karahan Sultan, bu zamana kadarki direnişlerinde başarısız olunca Safevî tarafını oyalamak düşüncesiyle Feridun Han’a ulaşmış ve onun aracılığıyla şahın huzuruna gidip af dilemiş̧iri ${ }^{10}$. Şaha

108 Bistamî, age., s. 76.

109 Müellif bu neviden bir zaferin Emir Timur'a dahi nasip olmadığını söyleyerek Feridun Han’a övgüler dizmekte ve Türkmenler karşısındaki başarısını onun gençliğine ve kahramanca duruşuna bağlamaktadır. Bistamî, age., s. 77-78.

110 Bistamî, Karahan Sultan'ın Şah Abbas'dan af dilemesi hadisesini samimiyetten uzak bir davranış olarak değerlendirdiğinden şöyle bir beyit kaleme almıştr. 
sadakat yeminleri etmesi üzerine hilat giydirilip Göklenler arasına gönderilmiştir. Bu esnada Karahan Sultan’a diğer isyancıların bağışlandığı da bildirilmiştir. Dolayısıyla Karahan Sultan Deşt-i Kıpçak’a döndüğünde aklında isyana karışan on beyleri ve Göklenler’i cezalandırmak düşüncesi yoktur. Buna rağmen bölgede kısa zamanda bir söylenti yayılmış ve Karahan Sultan'ın isyancıların önde gelenlerini öldüreceği diğgerlerini de tutuklatacağı dillendirilmiştir. Karahan Sultan'ın bağışlanması ve sonrasında Türkmenler arasında asılsız söylentiler yayılması Safevîler'in komplosudur. Feridun Han, izlediği bu politikayla Karahan Sultan ve on beyleri arasında güvensizlik yaratmıştır. Derhal bir mektup hazırlatan Feridun Han, Karahan Sultan'dan en sadık adamı Mevlana İmam Kulu'nun da dâhil olduğu 50 kişilik isyancı on beylerinin başlarını istemiştir. Üstelik bu mektup ulaklar tarafindan Karahan Sultan yerine Mevlana İmam Kulu'ya teslim edilmiştir ${ }^{111}$.

Mevlana İmam Kulu mektubu okur okumaz tüm Göklen halkını bir araya toplamiş ve onlara Feridun Han'dan gelen mektubun içeriğinden bahsederek uzun süredir Karahan Sultan'ın halkını cezalandıracağı yönünde kulaktan kulağa yayılan haberlerin gerçek olduğunu bildirmiştir. Son olarak Acaba bizim hatamız ve günahımız nedir ki o, bu kötü fikre kapılmış? Şu anda doğru olan budur ki o bizi kılıcla katlettirmeden önce elimizi çabuk tutalım ve onu asıl meskeni olan cehenneme gönderelim. demiştir. On beylerin hepsi bu konuşma üzere birlik olmuşlar ve gece vakti liderleri Karahan Sultan'1 katletmişlerdir. Ondan sonra bölgedeki Safevî idari binasını yakıp yıkmışlardır ${ }^{12}$.

Feridun Han, Sayın Hanîler’in gücünü zayıflatmak için çoğu zaman içlerinden sözü geçen birilerini yanına çekmeye çalışmış ve bu taktiği Türkmenlerin en zayıf anlarında uygulamıştır. Tevekkül Han-ı Giraylı önceki Göklen seferlerinden birinde mağlubiyeti dolayısıyla Safevî yönetimine boyun eğmiş Türkmenlerdendir. Hayatı bağışlanarak Feridun Han'ın hizmetine alınmış, Esterâbâd'da sonsuz lütuf ve ikram görmüş, kendisine itimat edilerek çeşitli görevler verilmiştir. Bu görevlerden biri de isyandan vazgeçen Göklenler'e aksakal tayin edilmesidir. Bundan sonraki süreçte de Sayın Hanî Türkmenleriyle mücadelede Feridun Han’ın yanında görev almıştır. Anlaşıldığı kadarıyla kendisine gösterilen lütuf ve ikrama rağmen Tevekkül Han yeniden isyan bayrağını kaldırmıştır. Böylece on dördüncü

\footnotetext{
Kendi sözüne ve sayısız affina (rağmen)

Delikten yılan çıkarabilirdi

به قول خوش و بخشش بـ شمار

Bistamî, age., s. 85 .

111 Bistamî, age., s. 86-87.

112 Bistamî, age., s. 88.
}

Belleten, Ağustos 2021, Cilt: 85/Sayı: 303; 507-544 
Türkmen seferi Tevekkül Han-ı Giraylı ve ona tabi Göklenler’e karşı gerçekleştirilmiştir. Bistamî, Tevekkül Han için tuzu haram (آن حرام نمك) ${ }^{113}$ sıfatını kullanmış ve bu davranışının yaşadığı coğrafyanın düşmanlık ve haydutluk ile yoğrulmuş toprağı ve suyundan kaynaklandığını ileri sürmüştür. Bu isyan dolayısıyla öncü birlikler Kızılca yurduna ilerlemişlerdir ${ }^{114}$. Feridun Han’ın da destek kuvvet olarak arkadan geleceğini öğrenen Göklenler on beylerini Esterâbâd valisini karşılaması için Sedd-i İskender civarına göndermişlerdir. Feridun Han’ın huzuruna çıkıp af dileyen on beyler Safevî Devleti'nin idaresini kabul ettiklerini bildirmişlerdir ${ }^{115}$. Ancak Feridun Han bu tabiiyeti kabul etmemiş olmalı ki Safevî birlikleri Kızılca kalesini kuşatma altına almış ve surları top atışlarıyla delik deşik etmişlerdir. Kızılca kuşatması neticesinde yaklaşık 850 Göklen’in başı kesilmiş çok sayıda ganimet ve esir ele geçirilmiştir ${ }^{116}$.

Safevîler'in Türkmenlerle mücadelede başvurduğu yöntemlerden bir diğeri Türkmenlerin yabancısı olduğu bölgelere iskânıdır. Bir vakitler Alimengi Hançer Sultan’a bağlı Türkmen boyu (ايل عليمنكى خنجر سلطان) çıkardıkları isyanlar nedeniyle devlet eliyle Mâzenderan'a iskân edilmişlerdir. Ancak iskândan memnun kalmayanlar karara karşı çıkıp bölgeyi terk etmişlerdir. Bu gelişme üzerine Şah Abbas'ın emriyle Kullar Ağası Rıdvan Bey isyana müdahale etmiştir. Dolayısıyla Safevîler'in on yedinci seferi Celayir bölgesine yerleşen Alimengi boyuna tertip edilmiştir. Bölgeye ulaşan Safevî birlikleri Türkmenlerin tamamını öldürmüştür ${ }^{117}$.

113 Bistamî, age., s. 137.

114 Bistamî, age., s. 138.

115 Bistamî, age., s. 139-140.

116 Bistamî, age., s. 140-143.

117 Bistamî boy halkının Safevî askerlerinin kılıcından kurtulamadığını söyleyerek Alimengi Türkmenlerinin tamamının öldürüldüğünü ima etmiştir. Bistamî, age., s. 153-155. 
Şah I. Abbas ve Sayın Hanî Türkmenleri Örneğinde Tahakküm ve Direniş

\section{Sonuç}

Safevî Devleti, Şah I. Abbas'ın saltanatıyla birlikte büyük değişimler yaşamıştır. Siyasi, idari ve askeri alanlarda kendini gösteren bu dönüşüm Hazar Denizi’nin güney doğusunda yaşayan Sayın Hanî Türkmenlerini de etkilemiştir. Şah Abbas tahta çıktığı andan itibaren Esterâbâd bölgesinin ve burada yaşayan halkın, devlet için ifade ettiği önemin farkındadır. Safevî hâkimiyetinin Horasan'ın kuzeyinde devamlılık göstermesi ve Safevî aleyhine şekillenecek Türkmen-Özbek yakınlaşmasını engellemenin en iyi yolu Esterâbâd vilayetinde istikrarlı bir yönetim kurmaktır. Şah Abbas bu ortamı sağlamak için önce yereldeki Türkmen beylerden istifade etmiştir. Yerel hâkimler uygulaması Türkmenlerin kendi arasında yaşadığı güvensizlikler ve seçilen yöneticinin Siyâh-puşân davasına ihanet ettiği algısı nedeniyle başarısızlıkla sonuçlanmıştır. Bunun üzerine gulâm sistemine geçmiş ve bölgeyi itimat ettiği Çerkes idarecilerin yönetimine bırakmıştır. Bu sistem de Feridun Han örneğinde olduğu gibi askeri müdahalelerin dışında bir başarı ortaya koyamamıştır.

Feridun Han, beylerbeyi olarak atanmasından ölüm yılına kadar sürekli küçüklü büyüklü Türkmen isyanlarını bastırmakla meşgul olmuştur. Safevîler düzenledikleri her seferle direnişi bastırmışlar fakat bu durum yeni isyanların ortaya çıkmasını engellememiştir. Kimi zaman çözüm Türkmen beylerin kızlarıyla yapılan evliliklerde aranmıştır. Kurulan ailevi bağların tarafları dostane ilişkilere sürüklemesi en azından Türkmenlerin yağma ve saldırılarına engel olması arzulanmıştır. Ancak bu taktiksel yaklaşım da sonuç vermemiştir. Çünkü Safevî yönetimi bölge halkının şikâyetlerine ve isyanlarına kalıcı çözümler bulmak yerine bölgede askeri güce dayalı otorite tesis etmekle meşgul olmuştur. Feridun Han son yıllarında halkın geçim sıkıntılarına kulak veren, onlara yeni iş sahaları oluşturan, gayr-i resmi alınan vergi ve hediye uygulamasını reddedip halkın ekonomik yönden kalkınması için firsatlar yaratan bir yönetici portresi çizmeye çalışmıştır. Anlaşıldığı üzere bu girişimler de yetersiz kalmış ve tüm Türkmenlere aynı oranda imkânlar sağlanamamıştır. Bu bağlamda Esterâbâd merkezi ile Bistam şehri Feridun Han’ın ekonomik destek politikasından en fazla istifade eden yerler olmuştur.

Feridun Han’ın Sayın Hanîler ile mücadelesini tüm ayrıntılarıyla ele alan Bistamî, Hanın Türkmenlere karşı toplamda yirmi fetih gerçekleştirdiğinden söz etmişse de yapılan incelemede taraflar arasındaki müzakere süreçlerinin, sulh ya da ittifak arayışlarının da Safevîler'in fetih hamlesi olarak not edildiği görülmüştür. Bu seferler yoğun olarak Göklen ve Oklu Türkmenleri üzerine gerçekleştirilmiş, Salur, 
Eymür, Giraylı ve diğer küçük gruplar da Safevî askeri müdahalelerine maruz kalmışlardır. Müellif Safevî -Sayın Hanî Türkmen savaşlarında açık bir şekilde taraf olmuş, Feridun Han'ın amacını tüm Deşt-i Gürgen bölgesi Türkmenlerine refah, adalet ve huzur sağlamak şeklinde ifade etmiştir.

Safevî ordusunun Türkmenler karşısında zafer sahibi olduğuna, onlardan çok sayıda kişiyi öldürdüğüne, hayatta kalanları esir edip mallarına el koyduğuna değinen Bistamî her seferden sonra Türkmenlerin insan kaybını küsuratlı sayllarla ifade ederken Safeviler'in kayılarından hiç bahsetmemiştir. Yazarın bu tavrı Safevîler’in Türkmenler üzerindeki üstünlügünü gözler önüne serme niyetinden kaynaklanmaktadır. Her savaşın korkunç bilançosu ise Türkmenlerin şikâyet ettiği sefalet hallerine son vermekten öte onların yaşam haklarının gasp edildiğine delildir. Öldürülen her bir Türkmen kellesinin mızrağa takılarak şehirlerde sergilenmesi de Safeviller'in bölgede oluşturduğu baskı ve korku halinin uzun yıllar belleklerden silinmemesine yol açmıştır. Dolayısıyla yeni Safevî valisinin adalet, merhamet ve hizmet sözleriyle yola çıkıp bağışlayıcılıktan uzak bir yönetim sergilediği ortadadır.

Genel itibariyle Safevî vakanüvislerinin görmezden geldiği Sayın Hanî Türkmenlerinin Münşî ve Bistamî tarafindan dinsizlik, hırsızlık ve açgözlülükle itham edilerek her firsatta aşağılanmaları, onların devlet otoritesine karşı çıkmaları ve devletin kurucu unsuru Kızılbaş valilere karşı sert tutum takınmalarının yanı sıra Sünni kimliklerinden de kaynaklanmaktadır. Buna rağmen Sayın Hanîler’in mezhep değişikliğine sonuna kadar direndikleri ortadadır. 
Şah I. Abbas ve Sayın Hanî Türkmenleri Örneğinde Tahakküm ve Direniş

\section{KAYNAKLAR}

Abisaab, Rula Jurdi, "Peasant Uprisings in Astarabad: the Siyâh Pûshân (wearers of black), the Sayyids, and the Safavid State", Iranian Studies, 49/3, pp. 471-492.

Afşar-fer, Nasır, "Nigâhî be Kitâb-1 Fütuhât-1 Feriduniyye", Ayne-i Mirâs, Devre-i Cedîd III/2, Tahran 1384.

Bellan, Lucien Louis, Zendegî-i Şah Abbas, tercüme Dr. Veliullah-1 Şâdân, İntişârât-1 Esatir, 1375.

Bir Şî̀/Katolik Oruç Bey Bayat/İranlı Don Juan, Tercüme ve Notlar: Tufan Gündüz, Yeditepe yay., Ankara 2014.

Bregel, Yuri, An Historical Atlas of Central Asia, Brill press, Leiden 2003.

Çınar, Gülay Karadağ, Safevî-Özbek Siyasî İlişkileri ve Osmanlı’nın Tesiri (1524-1630), Yayımlanmamış Dr. Tezi, Afyon Kocatepe Üniversitesi, Sosyal Bilimler Enstitüsü, Afyonkarahisar 2011.

Çınar, Gülay Karadağ, "Esterâbâd'da Safevî Hâkimiyetini Tehdit Eden Unsurlar: Siyâh-Puşân ve Sayın Hanî Türkmenleri”, Avrasya Uluslararası Araştırmalar Dergisi, 8/23, 2020, s. 108-132.

El-Zuveyri, Mahbub, "Siyâh-pûşân, şûreşiyân nâ-şenâhte-i asr-1 Safevî" Kitâb-ı Mâh-ı Târîh ve Coğrafya, Şomara 70-71, Şehriyor 1382, s. 50-54.

Felsefî, Nasrullah, Zendegânî Şah Abbas-ı Evvel, C I-III, İntişârât-ı İlmî, Tahran 1375.

Güner, Ahmet, "Kâbûs b. Veşmgîr", DİA, C 24, Türkiye Diyanet Vakfi yay., İstanbul 2001, s. 43-44.

Haneda, M. "Army iii.Safavid Period", Encyclopaedia Iranica,II/5 pp. 503-506, http://www.iranicaonline.org/articles/army-iii (ET: 14.06.2020).

İskender Bey Münşî, Târîh-i Âlem Ârâ-yı Abbasî, C II-III, haz. M. İ. Rıdvanî, Intişârât-ı Dünya-yı Kitâb, Tahran 1377.

İskender Bey Münşî-yi Türkmen, Târîh-i Âlem-Ârâ-yi Abbâsî, III. Cilt 1-2-3. Kısımlar, çev. Ali Genceli, Yay. Haz. İsmail Aka, TTK yay., Ankara 2019.

İskender Bey Münşî-yi Türkmen, Târîh-i Âlem-Ârâ-yi Abbâsî II. Cilt-1. Kitap 1-2-3. Kisımlar, çev. Ali Genceli, Yay. Haz. İsmail Aka, TTK yay., Ankara 2019.

İşraki, İhsan, "Çeşm-i Endâzî be Türkmânân-1 Esterâbâd der Asr-1 Safevî”" Ferheng, 
Şomara 43, Payiz 1381, s. 21-32.

Lockhart, Laurence, "Safevi Döneminde İran Ordusu", Cihannüma Tarih ve Coğrafya Araştırmalan Dergisi, Sayı II/2, çev. İlker Külbilge, 2016.

Mirza Muhammed Tahir Vahid Kazvinî, Târîh-i Cihân Ârâ-yn Abbasî (Abbasnâme), Tashih: Seyyid Said Mir Muhammed Sadık, İntişârât-ı Pejuheşgâh-ı Ulûm-ı İnsanî ve Mutâla‘ât-1 Ferhengî, Tahran 1383.

Molla Celaleddin Muhammed Müneccim Yezdî, Târîh-i Abbasîyâ Rûznâme-i Molla Celal, Be Kûşeş: Seyfullah Vahidniya, İntişârât-ı Vâhid, 1366.

Muhammed Tahir Bistamî, Fütûhât-ı Feriduniyye (Şerh-i Cenkhâ-yı Feridun Han-ı Çerkes Emirü'l-Umerâ-yı Şah Abbas-ı Evvel), Mukaddime ve Tashih: Seyyid Said Mir Muhammed Sadık-Muhammed Nadir Nasırî-yi Mukaddem, Neşr-i Nokte, Tahran 1380.

Reid, James J., "Rebellion and Social Change in Astarabad, 1537-1744", International Fournal of Middle East Studies, Vol. 13/No.1, 1981, pp. 35-53.

Reid, James J. "Esterabad'da İsyan ve Sosyal Değişim (1537-1744)" Türkmenler Üzerine Makaleler, çev. Resul Kürşat Şahsi, Selenge yay., İstanbul 2019.

Roemer, H.R., "The Safavid Period", The Cambridge History of Iran, Volume 6, Ed. Peter Jackson and Laurence Lockhart, Cambridge University press, England 2006.

Savory, R. M., "Allahverdi Khan (1)" Encyclopaedia Iranica, I/8, pp. 891-892, http:// www.iranicaonline.org/articles/allahverdi-khan-d-1, (ET: 14.06.2020).

Tapper, Richard, İran'ın Sinır Boylarnnda Göçebeler Şahsevenlerin Toplumsal ve Politik Tarihi, çev. F. Dilek Özdemir, İmge Kitabevi, Ankara 2004.

Tuğluca, Murat - Ülkü Küçük, "Osmanl Devleti'nde Savaş Esirlerinin İadesi: 1736 Osmanl-İran Anlaşması'na Göre Acem Esirlerin Teslimi Meselesi”, Osmanli'da Siyaset ve Diplomasi, Ed. Mehmet Yaşar Ertaş vd., Mahya Yay., İstanbul 2016, s. 57-73.

Veli Kulu bin Davud Kulu Şamlu, Kisasu'l-Hâkânî, C I, haz. Seyid Hasan Sadat Nasırî, Tahran 1371.

Veliyeva, Zülfiye, Safevi Devlet Teşkilatı (Tezkiretü'l-Mülük'e Göre), Yayımlanmamış Dr. Tezi, Ankara Üniversitesi Sosyal Bilimler Enstitüsü, Ankara 2007. 
Şah I. Abbas ve Sayın Hanî Türkmenleri Örneğinde Tahakküm ve Direniş

\section{EKLER}

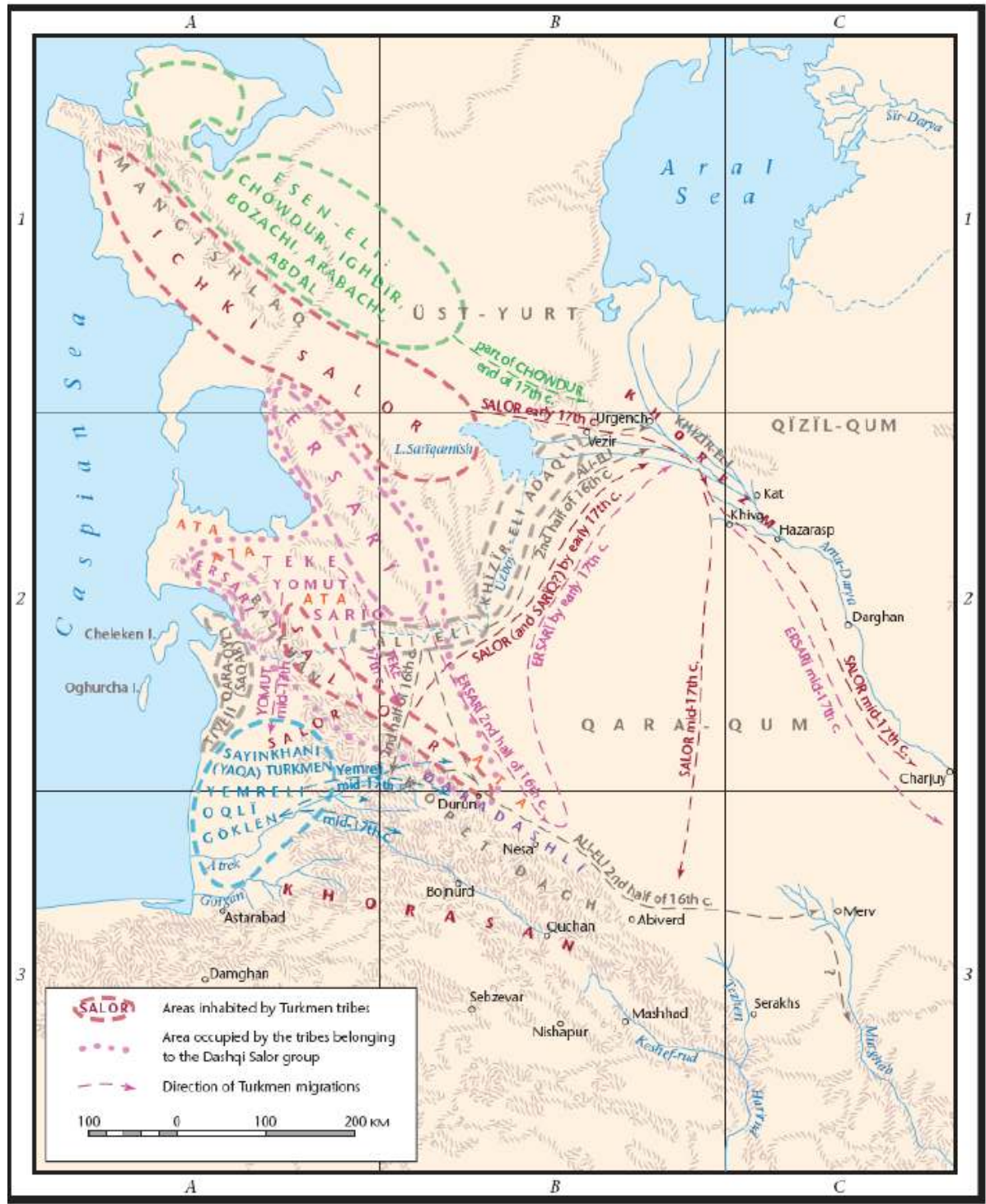

Ek 1: Esterâbâd/Deşt-i Gürgen

Kaynak: Yuri Bregel, An Historical Atlas of Central Asia, Brill press, Leiden 2003, s. 73. 


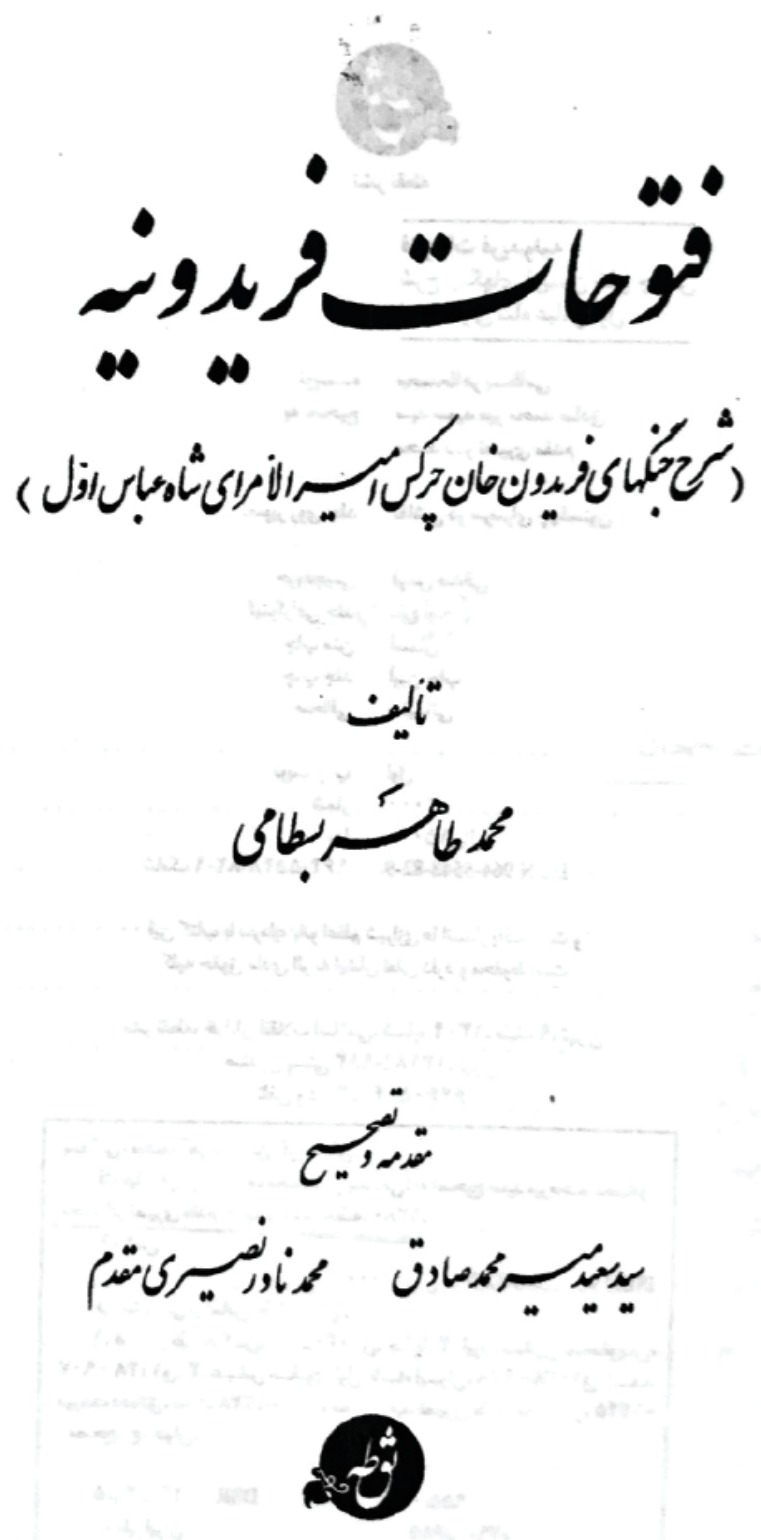

Ek 2: Fütûhât-ı Feriduniyye'nin Kapak Sayfası. 